\title{
Public choice and public health
}

\author{
Peter T. Leeson ${ }^{1} \cdot$ Henry A. Thompson ${ }^{1}$
}

Received: 3 March 2021 / Accepted: 12 March 2021 / Published online: 22 March 2021

(c) The Author(s), under exclusive licence to Springer Science+Business Media, LLC, part of Springer Nature 2021

\begin{abstract}
Public choice scholars have attended only modestly to issues in public health. We expect that to change rapidly given the Covid-19 pandemic. The time therefore is ripe for taking stock of public-choice relevant scholarship that addresses issues in public health. That is what we do. Our stock-taking highlights three themes: (1) Public health regulations often are driven by private interests, not public ones. (2) The allocation of public health resources often reflects private interests, not public ones. (3) Public health policies may have perverse effects, undermining instead of promoting health-consumer welfare.
\end{abstract}

Keywords Public choice $\cdot$ Public health $\cdot$ COVID-19 $\cdot$ Interest groups

JEL Classifications D72 · I18

\section{Introduction}

Public health is "The health of the population as a whole, esp. as monitored, regulated, and promoted by the state" (Oxford English Dictionary, 2020). Public choice is "the application of the principles of maximizing behavior...to institutions and behavior in the political world" (Tollison, 2004, p. 191). ${ }^{1}$ You might therefore think that public health has attracted major attention from public choice scholars. But then you would be wrong.

The Elgar Companion to Public Choice (Reksulak et al. 2014), an "authoritative and encyclopaedic reference work" of more than 600 pages that "provides a thorough account of the public choice approach", contains just six pages on which the term health (or a variant) appears. The Encyclopedia of Public Choice (Rowley \& Schneider, 2004), a two-volume reference work of more than a thousand pages that "provides a detailed and comprehensive account of the subject known as public choice", contains just a dozen pages on which the term appears. Not every discussion related to public health must or does include the word health. Still, the presence of but 6-12 index entries for the term in the major

\footnotetext{
1 And we would add, to institutions and behavior in nonmarket realms more generally.

Peter T. Leeson

PLeeson@gmu.edu

Henry A. Thompson

HThomps@gmu.edu

1 Department of Economics, George Mason University, MS 3G4, Fairfax, VA 22030, USA
} 
reference works on public choice suggests that public choice scholars have attended only modestly to issues in public health. ${ }^{2}$

We expect that to change rapidly given the Covid-19 pandemic, which is in full swing at the moment of writing. The time therefore is ripe for taking stock of public-choice relevant scholarship that addresses issues in public health. That is what we do. Our stock-taking highlights three themes: (1) Public health regulations often are driven by private interests, not public ones. (2) The allocation of public health resources often reflects private interests, not public ones. (3) Public health policies may have perverse effects, undermining instead of promoting health-consumer welfare.

Those themes would be at the center of any survey of public choice and public health. ${ }^{3}$ But they are not the only themes such a survey might consider. A different survey also might consider, for example, work that studies how differences in governmental institutions-democracies versus autocracies, presidential versus parliamentary systems, and federated states versus unitary ones-affect public health policies or outcomes. Our survey's focus on the themes enumerated above reflects our judgment of the primacy of rent seeking and government "failure" to analyses of the public sector in the public choice tradition. While that judgment is ours, it is not ours alone. Gordon Tullock titled his primer on public choice Government Failure (Tullock et al. 2002). James Buchanan described public choice as a "theory of government failure" (Buchanan, 1984, p. 11). And together with Robert Tollison, Tullock and Buchanan produced Toward at Theory of the Rent-Seeking Society (Buchanan et al. 1980). ${ }^{4}$

Even still, our survey's approach to public-choice relevant scholarship is quite broad. A few studies we consider were published before a subject called public choice existed. Numerous studies considered by us do not conceive of their contributions in terms of the public choice tradition but are in our view relevant to that tradition nonetheless. ${ }^{5}$ And less than $20 \%$ of the studies we consider were published in the journal Public Choice. Broad, however, is different from exhaustive and rather militates against it. Thus, while we endeavor to cover as much relevant scholarship as possible, we do not claim our coverage is complete.

\section{Public interests, private interests and public health}

The economic rationale for government health intervention is, like the rationale for other interventions, grounded in the theory of market failure fathered by Arthur Cecil Pigou (1920). That theory identifies departures of unhampered markets from the perfectively competitive model and describes policies for their correction. The approach to government most often married to the theory of market failure may be called the public interest approach. According to it, observed interventions are motivated by and corrective of market failures. The public interest approach to government implies that interventions increase

\footnotetext{
2 The situation is the same with The Oxford Handbook of Public Choice (Congleton et al. 2019). That twovolume reference work contains just five index entries that include the term health.

3 Or at least they should be.

${ }^{4}$ For a more ecumenical approach to public choice as applied to public health, see Costa-Font et al. (2020).

${ }^{5}$ Our summaries thus reflect our public-choice oriented interpretations of their analyses and findings. The interpretations or takeaways intended by their authors may differ.
} 
social welfare and produce the particular results they ostensibly seek, by, for example, promoting the welfare of particular consumers.

Kenneth Arrow (1963) pioneered the application of that approach to health. The literature his application inspired reflects "four broad categories of government action in healthcare markets, linked to corresponding market failures: healthcare as a merit good; informational gaps; infrastructure as a public good; and externalities" (Tuohy \& Glied, 2011, p. 58). Healthcare as a merit good refers to the idea that people care about others' health in addition to their own. Government responds by, for example, providing health insurance. Information gaps refer to differences in healthcare buyers' and sellers' knowledge. Doctors, for instance, know more about healthcare than patients. Government responds by, for example, licensing doctors. Infrastructure as a public good refers to the idea that investments in, for instance, biomedical research yield nonexcludable benefits. Government responds by, for example, subsidizing such research. Finally, externalities refer to the effects that people's health choices have on the health of other people. Smokers, for example, expose people around them to smoke. Government responds by, for instance, banning smoking in public places.

The public interest approach to government has a competitor: the "the public-choice, or interest-group approach" (McCormick \& Tollison, 1981, p. 3; italics added). According to it, observed interventions are driven by private interests and redistribute wealth. George Stigler (1971, 1976), Sam Peltzman (1976), McCormick and Tollison (1981), and Gary Becker (1983) pioneered the interest-group approach to government, whose principal building blocks - the logic of interest groups and rent seeking-were developed by Mancur Olson (1965) and Gordon Tullock (1967), respectively. The interest group approach to government conceives of politics as a market for wealth redistribution. That market's participants are self-interested politicians and citizens. Political influence requires costly political organization, and the cost of organizing politically varies over different combinations of citizens. ${ }^{6}$

The demand side of the market reflects combinations of citizens who can organize for less than a dollar to secure a dollar in transfers through favorable intervention. The supply side reflects combinations of citizens for whom it would cost more than a dollar to organize to prevent having it transferred from them through unfavorable intervention. Politicians are market middlemen whose "arbitrage" efforts are remunerated by votes and campaign contributions - the "price" that transfer-demanders pay politicians to redistribute wealth to them from transfer-suppliers. Politicians thus maximize their remuneration by transferring wealth from combinations of citizens who resist the least to those who value transfers the most. The interest group approach to government implies that interventions redistribute wealth to well-organized groups of citizens who anticipate large per capita gains from poorly organized groups of citizens who anticipate small per capita losses. A corollary is that interventions need not increase social welfare, may instead reduce it, and may produce particular results that are at odds with the outcomes the interventions ostensibly seek.

Thirty years ago, two papers beckoned public choice scholars to apply the interest group approach to government to issues in public health. The first, authored by public choice economist Gary Anderson (1990, p. 558), lamented that "public health has largely ignored the public choice revolution." The second paper, authored by public choice economists Tollison and Wagner (1991, p. 323), lamented that the public choice revolution largely has

\footnotetext{
6 That cost includes not only the expense of organizing per se but also of, for example, obtaining information and controlling organizational free riding.
} 
ignored public health: "While there is now an extensive body of scholarship...on the interest-group approach to political processes, public health is one significant area of governmental activity that...has not been brought under such analytical scrutiny." The following sections survey public-choice relevant scholarship that address issues in public health.

\section{Private interests and public health regulation}

The earliest inklings of public choice's relevance to health regulation were sensed before a subject called public choice existed. They belong to Friedman and Kuznets (1945), who found that American physicians earned supernormal returns. Friedman and Kuznets attributed those returns to physician licensing regulations that restrict occupational entry, lobbied for by the American Medical Association (AMA). In 1962-the same year that Buchanan and Tullock published their Calculus of Consent-Friedman expanded upon the suggestion in his Capitalism and Freedom. There he observed that while government regulation is couched in terms of protecting the public, regulation often benefits and is driven by well-organized producer groups such as the AMA.

The largest public-choice relevant literature that addresses issues in public health builds on Friedman's insight in various ways. We consider that literature below. We summarize but do not evaluate the validity of the arguments or findings in these studies or those we consider in later sections. Their arguments or findings could, however, be challenged, and some of them have been challenged in studies we do not consider. Furthermore, we summarize only the arguments or findings of each study that are in our view most relevant to the interest group approach to government. Readers who desire a complete picture should consult the studies referenced.

\subsection{Food and drugs}

Food and drugs are principal objects of public health regulation. Their quality is important for consumer health and, perhaps less obviously, the regulation of their quality furnishes opportunity for well-organized interest groups to redistribute wealth from competitors and consumers to their members. Libecap (1992), for example, investigates the origins of America's first federal food-quality regulation: the Meat Inspection Act of 1891. That act required federal inspection and quality certification of cattle to be exported and of cattle to be slaughtered for interstate trade or export. Its stated purpose was to protect consumers from diseased cattle and low-quality meat. Libecap, however, contends that no significant diseased cattle or low-quality meat problem existed at the time the Meat Inspection Act was passed. Rather, the law was driven by rent-seeking local slaughterhouses, which in the late nineteenth century came under pressure from a new competitive threat.

That threat was posed by a handful of large Chicago-based meatpacking firms, the socalled "Beef trust." In contrast to local slaughterhouses, which slaughtered cattle for local sale, the Chicago packers slaughtered cattle and then shipped dressed meat to local markets across the country. This supply-chain innovation leveraged improvements in refrigeration and transportation, resulting in lower meat prices. Meat consumers thereby benefited. Local slaughterhouses thereby were harmed.

In response, local slaughterhouses organized politically as the Butchers' National Protective Association. The Association charged Chicago packers with slaughtering diseased cattle and selling unwholesome (dressed) meat, putting consumers' health at risk. With 
that concern as rent-seeking camouflage, the Association lobbied successfully for federal inspection and certification of cattle to be slaughtered for interstate trade. The regulation was a device for hampering the interest group's competition. Its burden fell on the Chicago packers, whose cattle were slaughtered for sale across the country, but was avoided by local slaughterhouses, whose cattle were slaughtered for local sale. ${ }^{7}$

Stanziani (2007) examines food-quality regulations in late nineteenth- and early twentieth-century France. During that period technical progress in France resulted in innovations such as raisin wine, margarine, and skimmed milk. Hygienist groups protested the safety of those innovations. But according to Stanziani, the validity of their protests was doubtful. Food-quality regulations in historical France were instead the product of rent seeking by well-organized interest groups.

The invention of raisin wine, margarine, and skimmed milk threatened the incomes of France's traditional producers of wine, butter, and milk. The traditional producers thus sought to limit competition from the producers of innovative foods. ${ }^{8}$ To do so, interest groups composed of traditional food producers allied politically with the hygienists, whose concerns about innovative-food safety they leveraged for rent-seeking cover. The joint lobbying efforts of the interest groups secured governmental designations of innovative food products as "adulterated". That designation subjected innovative foods to costly restrictions, rendering them less competitive.

The political alliance of groups with seemingly disparate interests-like traditional food producers and hygienists - is an important subtheme in other public-choice relevant analyses of public health regulation. Such alliance commonly is called the "bootleggers and Baptists" phenomenon, a term coined by Bruce Yandle (1983). We consider Yandle's bootleggers and Baptists model in Sect. 3.2, which addresses alcohol regulation.

Dupre (1999) studies margarine regulations in late nineteenth- and early twentiethcentury North America. Between 1886 and 1949, Canada's federal government outlawed margarine. Most American state governments were content merely to outlaw the artificially yellow variety, while the US federal government subjected yellow margarine to discriminatory taxation. Governments in both countries justified margarine regulations in terms of public interest: to protect consumer health and prevent fraud. Dupre, however, provides evidence that margarine regulations were designed to protect well-organized dairy producers from the competition of politically weaker margarine manufacturers, whose butter substitute was less expensive (see also Gifford, 1997).

In the United States local, state, and national dairy associations originated the idea of margarine regulation and saw to it that their idea became law. In Canada, margarine regulation was the product of lobbying by provincial dairymen's associations. America's margarine regulations were repealed only after American margarine manufacturers switched from sourcing their inputs abroad to sourcing them domestically. That substitution earned American margarine manufacturers political support from American soybean, cotton, and cattle farmers - the domestic input suppliers (soybean oil, cottonseed oil, and beef fat) who now benefited from margarine deregulation. The American Soybean Association

\footnotetext{
7 According to Libecap (1992), the Meat Inspection Act was lobbied for and passed alongside the Sherman Act of 1890. The latter's success was influenced by an interest group composed of midwestern cattle raisers, which charged the "Beef trust" with colluding to suppress cattle prices.

8 Thomas and Leeson (2012) study beer regulation in fourteenth- through sixteenth-century Bavaria, which culminated in the Bavarian Purity Law of 1516. They argue that the regulation was the result of rent seeking by interest groups in response to a critical beer innovation, namely hops.
} 
and the National Cotton Council thus joined with the National Association of Margarine Manufacturers, whose collective interest-group influence proved sufficient to see deregulation through. Canada's federal margarine ban was repealed only after WWII ended and the price of butter skyrocketed, making the ban's continuation untenable. Canadian provinces, however, continued to regulate margarine until the 1970s, and well beyond in the case of Ontario. Dupre finds that in states or provinces with higher per capita butter output, margarine regulation was more severe. In states or provinces with higher per capita cattle and cotton output, margarine regulation was less severe.

Wood (1985) analyzes America's Food and Drug Act of 1906 (see also Anderson, 1990). That act defined "adulterated" and "misbranded" food and drug products and prohibited their trade across states. Its stated aim was to protect consumers by promoting food and drug quality. And according to Wood, consumer information about product quality did improve after the Food and Drug Act passed. Yet critical support for the law came from a variety of producer interest groups whose members desired food and drug regulation to enforce industry cartels, to restrict entry into their industries, to reduce costs for producers of complementary inputs, or to increase costs for producers of substitutes. Among such interest groups were, for example, undercapitalized dairy farmers and creamery owners threatened by competition from margarine; bottled-in-bond whiskey distillers threatened by competition from rectified whiskey; established pharmaceutical manufacturers threatened by competition from patent medicines; and traditional cream of tartar baking powder manufacturers threatened by competition from inexpensive acid-based baking powders. The rent-seeking success of those producers owed to their better organization than that of the producers (and consumers) from whom the Food and Drug Act's regulations transferred wealth.

Leeson et al. (2020) study England's Pharmacy Act of 1868. That act designated as "poisons" various substances then commonly used in medicine, such as opium and emetic tartar, and prohibited all but medical professionals from selling products containing those substances. ${ }^{9}$ The act's stated purpose was to protect consumers from dangerous substances. But Leeson et al. argue that its actual purpose was to protect medical professionals from the competition of patent medicines and patent medicine vendors.

Patent medicines were medicaments manufactured by tradesmen that contained the same, often dangerous substances found in the medicines that medical professionals compounded and dispensed. Patent medicine vendors were shopkeepers who retailed such medicines but whose primary business was non-medicinal: grocers, stationers, and nearly every other kind of shopkeeper in between. Then as now, medical professionals were expensive. And because nineteenth-century medical knowledge was very crude, the diagnostic and therapeutic prowess of medical professionals did not differ much from that of most laymen. Patient self-treatment with patent medicines or other medicaments that used the same substances, which also were available from patent medicine vendors, therefore was routine.

A trip to the grocer was thus a close substitute for calling on a medical professional, and less expensive to boot. To address this competitive threat, the British Medical Association and the Pharmaceutical Society of Great Britain lobbied parliament for a monopoly on the sale of medicaments that contained popular albeit dangerous substances. And with the Pharmacy Act they succeeded-but initially, only in part. Counter-lobbying by patent medicine manufacturers managed to secure an exemption for their medicines from the

9 The act also required that such medicines be labeled "poison". 
Pharmacy Act's regulations. The grocer no longer could sell lumps of opium, now saleable only by medical professionals. But he could still sell patent medicines that contained opium, a large loophole that medical professionals could not afford to countenance. The British Medical Association and the Pharmaceutical Society of Great Britain thus took their rent-seeking efforts to England's courts. There they succeeded in securing an interpretation of the Pharmacy Act that brought patent medicines under its purview.

\subsection{Alcohol}

Alcohol is intoxicating. Its consumption therefore may affect not only the consumer's health but also the health of third parties, for example in the case of drunk driving. Furthermore, alcohol is an object of public health policy. Its regulation thus may be exploited by well-organized interest groups to secure rents for their members. Yandle (1983, 1999), for instance, considers US state and local regulations that govern when alcohol may be sold. These so-called "blue laws" typically prohibit or restrict alcohol sales on Sundays. To explain alcohol regulation's provenance, Yandle develops a "bootleggers and Baptists" model, which Yandle describes as an extension of the "Stigler-Peltzman special-interest theory of regulation" (Yandle, 1999, p. 7). ${ }^{10}$ The bootleggers and Baptists model arises from two observations. First, interest group support for regulation often comes from apparently disparate quarters: rent seeking makes strange bedfellows. Second, when it comes to securing political support for a regulation that an interest group desires, often "neither well-varnished moral prompting nor unvarnished campaign contributions can do the job alone. It takes both" (Yandle, 1999, p. 7).

Bootleggers seek blue laws because those laws restrict competition from legal alcohol vendors. Baptists seek blue laws because Baptists object morally to alcohol consumption. Working together, the members of this curious coalition can secure the political support required for regulation that neither interest group could manage on its own: restrictions on alcohol sales or, once such restrictions are in place, preventing their repeal. Bootleggers grease the political wheels by promising to share profits with politicians. Baptists supply a credible moral foundation for alcohol regulation. ${ }^{11}$

Horpedahl (2020) tests Yandle's model in contemporary Arkansas, where some counties are "wet" and other counties, operating under blue laws, are "dry". Horpedahl finds that (literal) Baptist organizations and liquor stores in wet counties that border dry ones have, by co-lobbying, succeeded in blocking numerous attempts to repeal blue laws in dry counties. When Baptist groups alone have attempted to block blue-law repeal, they have been less successful.

Smith (1982) studies US state regulations on the sale of alcoholic beverages, such as alcohol taxes, licensing, and advertising restrictions. The stated purpose of the regulations is to reduce alcohol externalities such as drunk driving, unwanted exposure to drinking, and unwanted exposure to messages that encourage alcohol consumption. Smith, however, argues that alcohol-sales regulations are adopted to redistribute wealth to the members

\footnotetext{
${ }^{10}$ Smith and Yandle (2014) apply the bootlegger and Baptist model to a variety of regulations besides those affecting alcohol, e.g., tobacco, drugs, the environment, the US Troubled Asset Relief Program of 2008, and the US Affordable Care Act of 2010.

11 Shogren (1990) points out that because bootleggers usually have an incentive to subsidize the lobbying activities of Baptists, whose motive is "non-economic", estimates of rent-seeking costs that focus on lobbying whose motive is "economic" may be too low.
} 
of well-organized interest groups. Smith identifies four such groups with an interest in alcohol-sales regulation: licensees, temperance groups, regulators, and the tourism industry. The public interest approach to government predicts, for example, that in states with larger tourism industries, alcohol-sales regulations will be more stringent, for more tourism means larger alcohol externalities. The interest group approach to government, in contrast, predicts that alcohol-sales regulations in such states will be less stringent, for alcohol is a complement to tourism. Smith finds support for the interest group approach to government. A larger tourism industry, for instance, is associated with alcohol-sales regulations that are less strict, not more so.

Urban and Mancke (1972) investigate whiskey labeling regulations in early twentiethcentury America. In the years just after national prohibition ended, America's market for domestic whiskey had two competing segments: heavy bodied whiskey, which after distillation was kept in new barrels, and light bodied whiskey, which after distillation was kept in less expensive, reused barrels. Domestic light bodied whiskey therefore was less expensive than domestic heavy bodied whisky.

In 1935 the US Federal Alcohol Administration (FAA) introduced a regulation according to which a whiskey's "age" had to be printed on the labels of domestic whiskey traded across state lines. "Age", however, was defined not by the length of time whiskey had in fact been aged but by the length of time it had been kept in new barrels. Domestic distillers of light bodied, but not heavy bodied, whiskey thereby were compelled to label their products with the discouraging statement "less than one month old".

The alleged purpose of this regulation was consumer protection. The FAA averred that keeping whiskey in new barrels promoted uniformity in its quality. Hence, if whiskey were kept in reused barrels, it was crucial that consumers be made aware of the fact and that the whiskey's unreliable quality be implied. Urban and Mancke argue that consumer protection could not have been the actual aim of the labeling regulation, however, since imported light bodied whiskey, which likewise was kept in reused barrels, explicitly was exempted by the FAA from its labeling regulation.

Rather, the aim of the regulation was to protect American distillers of heavy bodied whiskey from the competition of American light bodied whiskey-the less expensive substitute. Imported light bodied whiskey, in contrast, posed no competitive threat. Given the cost of shipping it from overseas, imported light bodied whiskey was more expensive than American heavy bodied whiskey even though the former was, like American light bodied whiskey, kept in reused barrels. Hence, imported light bodied whiskey was exempted from the labeling regulation, which targeted domestic light bodied whiskey exclusively. American coopers (barrel manufacturers) joined heavy bodied whiskey distillers in securing the discriminatory labeling regulation. And their motivation, too, was redistributive. The demand for barrel manufacturers' output-new barrels-was threatened by domestic light whiskey distillers' reliance on reused barrels.

Whiskey labeling regulation also is the subject of High and Coppin's (1988) study, which examines whiskey's treatment under America's Pure Food and Drug Act of 1906. That law, considered above, required distillers of rectified whiskey to label their products "imitation whiskey", whereas distillers of straight (unrectified) whiskey enjoyed the label of "pure whiskey". The regulation's alleged aim was consumer protection. Yet according to High and Coppin, the whiskeys were almost identical chemically, save for the fact that straight whiskey contained more poisonous fusel oil. Consumer protection, therefore, was not the actual goal of the Food and Drug Act's whiskey labeling regulation. Wealth redistribution was. High and Coppin rely on the personal letters of Harvey Washington WileyChief Chemist of the Department of Agriculture's Bureau of Chemistry (predecessor 
agency of the FDA) and principal architect of the Food and Drug Act-to show that Wiley sought and received support for the act from straight-whiskey distillers eager to limit competition from rectified-whiskey distillers.

Munger and Schaller (1997) study the constitutional ratification and repeal of alcohol prohibition in the United States. They argue that the Eighteenth and Twenty-first Amendments reflected the shifting relative strengths of two interest group coalitions: "dry" and "wet". Dry interests included the Anti-Saloon League, Women's Christian Temperance Union, and industrial elites such as John D. Rockefeller, Jr.-each of whose members objected on moral grounds to legalized alcohol — and bootleggers, who objected financially. Wet interests included the United States Brewers' Association and the National Wholesale Liquor Dealers Association, both of which were more poorly organized than dry interests leading up to prohibition.

Dry interests thus prevailed in the initial contest over alcohol's legal status, resulting in the Eighteenth Amendment, which criminalized the manufacture, transport, and sale of alcohol. ${ }^{12}$ Yet wet interests ultimately would prevail, resulting in the Eighteenth Amendment's repeal by the Twenty-first Amendment, which legalized alcohol. Munger and Schaller show that three crucial differences accounted for the reversal. The first was time, which permitted wet interests to (re)organize more effectively - this time to include, for example, the Association Against the Prohibition Amendment, representing a range of economic interests, and the American Federation of Labor, representing brewer labor unions. The second difference was the passage of the Nineteenth Amendment, which in granting women the right to vote drained women's political organizations-important to dry interests — of much of their energy. The final difference was the Great Depression, which prompted government to find new sources of revenue, such as taxing alcohol.

Poelmans et al. (2018) consider America's Cullen-Harrison Act of 1933. That law, passed nine months before the ratification of the Twenty-first Amendment, legalized the production and sale of low-alcohol beverages (3.2\% alcohol by weight) federally. States, however, remained free to continue to ban alcohol in their domains. Poelmans et al. find that the strength of historical brewing interests in a legislator's state is a strong positive predictor of his/her support for the Cullen-Harrison Act and also is a strong a positive predictor of the speed at which a state amended its alcohol laws to take advantage of the Cullen-Harrison Act after its passage. Poelmans et al. find no evidence that the preferences of voters mattered for their representatives' support for the law.

\subsection{Tobacco}

Like alcohol consumption, tobacco consumption may affect the health of third parties in addition to the health of the consumer, for example in the form of second-hand smoke. And like alcohol regulation, tobacco regulation is fertile ground for rent-seeking interest groups. Tollison and Wagner $(1988,1992)$, for instance, consider US “Clean Indoor Air

\footnotetext{
12 Anderson (1997) argues that reliance on prohibitions versus sin taxation may be explained by the interest of enforcement bureaucrats in the former versus the latter. Sin taxes generate relatively modest demand for enforcement activities, and sin tax revenues typically are shared by different government agencies. Prohibitions, in contrast, generate maximal demand for enforcement activities, and governmental budgets for enforcement agencies are enjoyed by those agencies alone. Prohibitions therefore increase the budgets of enforcement agencies more than taxes do. Enforcement bureaucrats thus have an incentive to transform tax regimes into prohibition regimes.
} 
Acts": state regulations that restrict or prohibit smoking in spaces such as restaurants and workplaces. The stated aim of the regulations is to protect consumer health from smokerimposed external costs. Yet that cannot be the regulations' actual aim, Tollison and Wagner contend, since no such externalities exist in privately owned restaurants and workplacesan argument we return to in Sect. 6.2.

Government indoor-smoking bans instead reflect the efforts of interest groups to redistribute wealth from smokers to their nonsmoking counterparts. One such interest group consists of nonsmoking workers (Shughart \& Tollison, 1986). To attract such workers away from firms that do not permit workplace smoking, firms that permit workplace smoking must pay nonsmoking workers a wage premium. If government then bans workplace smoking, nonsmoking workers reap transitory rents. Current nonsmoking employees temporarily enjoy the wage premium plus the workplace environment they prefer, and potential nonsmoking employees enjoy a competitive advantage over potential smoking employees, who require a wage premium to induce them to work in the mandated workplace environment and thus are now relatively more expensive to hire. Faced with less competition from potential smoking employees, potential nonsmoking employees temporarily earn higher wages. The prospect of these short-run rents may motivate nonsmoking workers to support legislation that bans workplace smoking. A second interest group motivated to ban indoor smoking consists of nonsmoking bar- and restaurant-goers. Smoking bans increase the supply of nonsmoking bars and restaurants, resulting in lower prices for the group's members. ${ }^{13}$

Several studies consider tobacco excise taxes in the US states. Tollison and Wagner (1988, 1992), for example, argue that labor unions may benefit from such taxes and thus may have an interest in supporting them politically. Tobacco taxes fall disproportionately on the poor, who are overrepresented among smokers. Hence, when tobacco is taxed more heavily, those individuals find it more difficult to get the education and training required to enter the workforce as skilled laborers. As a result, they find it more difficult to enter the workforce as competitors to labor unions. Smokers, Tollison and Wagner argue, are poorly positioned to resist antitobacco interventions because unlike, for example, union laborers, "They face high organization costs" and, given their lower incomes, they have "relatively meager resources as a group to fight" the interventions (Tollison \& Wagner, 1988, p. 82).

Holcombe (1997) observes that the public interest account of tobacco taxes construes them as reflecting Pigouvian considerations and reasons that, if true, one would expect US states that rely more heavily on that excise tax also to rely on more heavily on other excise taxes, for example on gasoline. In contrast, if the interest group account of tobacco taxes is correct, one would expect no relationship across states between tobacco and gasoline taxes, but one would expect a negative relationship between the strength of tobacco interest groups and tobacco taxes. Holcombe reports support for the interest group account. While no relationship across states between per-pack cigarette taxes and per-gallon gasoline taxes is found, cigarette taxes are lower in states with more tobacco acres per capita.

DiLorenzo (1997) studies California's Proposition 99, a tobacco-related amendment to the state constitution passed in 1988. That proposition more than tripled the state's tax

\footnotetext{
13 Prinz (2009) notes the possibility that some restrictions on tobacco may in fact be desired by the tobacco industry. He reasons that insofar as tobacco regulations are a response to tobacco externalities, restrictions that reduce unwanted tobacco-related exposure may weaken government's interest in imposing more costly regulations on the tobacco industry, such taxing tobacco. Provided that such restrictions do not reduce tobacco use, they therefore may be sought by the tobacco industry.
} 
on cigarettes and was expected to raise more than half a billion dollars annually, much of it earmarked for tobacco research, antismoking education, and treating indigent hospital patients. DiLorenzo argues that Proposition 99 was driven by rent seeking on the part wellorganized healthcare interest groups: the American Cancer Society, the California Medical Association, the American Lung Association, and the American Heart Association. These interest groups spent $\$ 400,000$ lobbying for the proposition, which they advanced under the cause of protecting consumer health. By raising the tax on cigarettes, cigarette consumption would be discouraged. Yet DiLorenzo observes that if less smoking were the interest groups' actual motive for the tax increase, they would have pursued its adoption through the state legislature. A legislative cigarette tax increase would have reduced cigarette consumption just the same. It would not, however, have permitted healthcare interest groups to appropriate the additional cigarette tax revenue.

The reason for adopting a proposition tax strategy was an amendment to California's constitution that limited state spending. This amendment meant that if the state spending cap were reached, the state would have to return cigarette tax revenue to citizens instead of spending it on health research, education, and services-outputs supplied by members of the healthcare interest groups. The interest groups' solution was to seek the cigarette tax hike in a statewide referendum - as a further constitutional amendment - thereby circumventing the spending limit and ensuring that hundreds of millions of additional cigarette tax dollars would be spent on the goods and services supplied by their members.

Adler et al. (2016) examine US Food and Drug Administration (FDA) regulation of electronic cigarettes. In 2016 the FDA designated e-cigarettes as tobacco products, subjecting them to federal tobacco regulation that, among other things, requires premarket approval. The ostensible justification for regulating e-cigarettes in the manner of traditional cigarettes is their equivalent health risks. That, however, seems doubtful since e-cigarettes contain no tobacco and research suggests they are less dangerous than traditional cigarettes.

Rather, Adler et al. argue, the FDA's decision to treat e-cigarettes as tobacco products reflects rent seeking by four well-organized interest groups that joined in a de facto bootlegger-and-Baptist coalition to encourage the regulatory decision: producers of traditional cigarettes, drug manufacturers, legislators, and antismoking groups. E-cigarettes are substitutes for both traditional cigarettes and nicotine replacement therapies. Hence cigarette producers and drug manufacturers sought the FDA designation to increase their competitor's costs. Legislators, meanwhile, desired it to preserve the returns to state "tobacco bonds". Those bonds securitize state tobacco revenues, which are threatened by e-cigarettes if e-cigarettes are not defined as tobacco but may grow if e-cigarettes are defined as tobacco. Antismoking groups acted as the Baptists in this coalition, providing moral high ground with concern that e-cigarettes would normalize smoking, prolong nicotine addiction, and have as-of-yet-undiscovered adverse health consequences.

\subsection{Fat taxes}

Sugary food and beverages differ from alcohol and tobacco in that their consumption cannot affect the health of third parties. They are similar to alcohol and tobacco, however, in that they may pose health risks to those who consume them. Sugary food and beverages have been linked to, for example, obesity and type 2 diabetes. For that reason, such products may be subjected to "sin taxes", a term commonly applied to excise taxes that target 
alcohol, tobacco, and gambling. ${ }^{14}$ In the case of sugary food and beverages, however, such taxes commonly are called "fat taxes". ${ }^{15}$ Fat taxes threaten the interests of sugary food and beverage producers, who thus have an incentive to lobby against them.

Hoffer et al. (2014) consider federal excise taxes on sugar-sweetened beverages in the United States. In 2009 the US Senate proposed a federal tax on soft drinks, allegedly to promote public health by discouraging soft-drink consumption. The proposal ultimately was defeated. Hoffer et al. argue that the fat tax proposal and its defeat reflected what public choice scholar Fred McChesney (1987) dubbed "rent extraction". US Senators threatened to impose costs on the soft drink and fast-food industries to motivate campaign contributions and political support from those industries in exchange for not following through with the tax. The extraction was successful. Lobbying by the soft drink and fast-food industries rose dramatically after the proposal, and the federal soft-drink tax was killed. ${ }^{16}$

\subsection{Health-occupation licensing and commercial restrictions}

The health of consumers is affected not only by the food, drugs, and other substances they consume but also by the quality of the health services they consume. Ostensibly to assure the quality of those services, regulation governing who may provide them-healthcarerelated occupational licensing - is a prominent instrument of public health. Because occupational licensing empowers healthcare providers to restrict entry, it also is a prominent instrument for redistributing wealth from would-be occupational entrants, competitors, and consumers to the members of health-service providing interest groups.

Among the earliest scholars to emphasize this idea was Kessel (1958) who, echoing Friedman and Kuznetz (1945), argued that the American Medical Association is a profitmaximizing cartel that uses government licensing to secure rents for incumbent physicians. Subsequent public-choice relevant scholarship on healthcare-related occupational licensing extends and explores such thinking. Maurizi (1974), for example, considers the relationship between the demand for entry into a variety of healthcare occupations, running from osteopathy to optometry, and the difficulty of required occupational-entrance exams created by licensing boards dominated by incumbent practitioners. Maurizi finds that excess demand for entry is associated with lower exam pass rates. He interprets this finding as evidence that health-occupation licensing is used by incumbent healthcare-service providers to secure rents.

Paul (1982) examines the relationship between the method of selecting US state medical licensing boards and the incomes of physicians. In some states, the members of medical licensing boards are appointed by state medical associations. In other states, the governor appoints them. Paul finds that where licensing boards are appointed by medical associations, physicians' incomes are higher. He concludes from the evidence that "licensure

\footnotetext{
14 Shughart (1997) critiques the coherence of the most common public-interest justifications for sin taxes. Lee (1997) argues that citizens tend to object less strongly to sin taxes than to general taxes because the former permit citizens to feel virtuous. Because tax revenues largely are fungible, governments therefore may rely on sin taxes, whose revenues are earmarked for "virtuous" purposes, to raise tax revenues when citizens would otherwise resist tax increases.

15 For further discussion of such taxes, see Hoffer and Nesbit (2018).

16 Soft drink taxes were, however, later imposed by some local governments. Shughart and Smith (2020) highlight the problem of using Pigouvian logic to justify such taxes and consider the disconnect between public expenditures and public revenues in the context of soft drink taxes.
} 
restrictions are used to limit entry into medicine, and result in wealth being transferred from medical service consumers to producers of those services" (Paul, 1982, p. 568). Paul contradicts Leffler (1978), who in a well-known paper argued that medical licensing requirements in the United States are demanded by consumers to, for example, address informational asymmetries.

In a similar vein, Broscheid and Teske (2003) consider the relationship between consumer and physician representation on US state medical boards and physician licensing requirements. Physician representatives dominate all state licensing boards. Some boards, however, require more consumer representatives than others. Broscheid and Teske find that the latter boards are associated with physician licensing requirements that have educational justification and thus are more likely to reflect concerns about assuring physician quality. In contrast, boards with stronger physician representation are associated with licensing requirements that are difficult to justify on quality assurance grounds and thus are more likely to reflect physician interest-group rent seeking. Broscheid and Teske's analysis builds on Svorny and Toma (1998), who find that state medical licensing board freedom from legislative budgetary oversight facilitates physicians' use of licensing to restrict occupational entry in the service of rent creation.

Adams et al. (2003) study US state licensing regulations for nurse-midwives. In a supply and demand framework, licensing for midwifery has two effects. First, by restricting the number of service providers, it reduces the supply of midwife services. Second, by assuring minimum midwife quality, licensing increases the demand for such services. Both forces raise the price of midwife services, but they have opposing effects on service quantity. If licensing primarily reflects concern for addressing deficient consumer information about midwife service quality, it should increase the demand for midwife services more than it reduces the supply of those services, yielding a net increase in the quantity of midwife services consumed. If, however, licensing primarily reflects rent seeking by occupational incumbents, the reverse should be true, yielding a net reduction in the quantity of midwife services consumed. Adams et al. find that midwife licensing results on balance in fewer midwife services consumed. Svorny (1987) conducts an analogous test in the context of US state licensing regulations for physicians and finds similar results.

Peterson et al. (2014) study licensing regulations for migrant physicians in the US states. Those regulations establish criteria for the assessment and recognition of medical occupational qualifications earned in foreign countries. Their ostensible purpose is to assure physician quality. That purpose, however, is doubtful since international medical graduates seeking licensure in the United States must complete the same standardized tests as US medical graduates and compete for limited post-graduate residency positions. Rather, Peterson et al. argue, licensing regulations for migrant physicians are explained by rent-seeking native physicians, who seek more stringent licensing criteria for international medical graduates to limit competition. Peterson et al. find that states with greater physician control over licensing requirements impose more stringent requirements for migrant physician licensure and receive fewer new migrant physicians.

McMichael (2017) examines the political activity of healthcare provider interest groups directed at influencing occupational licensing in the US states. Nurse practitioners and physician assistants are close substitutes for physicians in terms of knowledge, training, and service quality. Nurse practitioners and physician assistants also are less expensive. Physician interest groups thus have an incentive to restrict competition from nurse practitioners and physician assistants. In contrast, hospital interest groups, whose members seek to keep costs down by relying more heavily on nurse practitioners and physician assistants, have an incentive to resist regulation that would make doing so more difficult. 
Political campaign contributions are a way that both sets of interest groups can improve their chances of securing favorable regulation. McMichael finds that more political spending by physician interest groups increases the probability that a state maintains licensing laws that restrict the scopes of practice of nurse practitioners and physician assistants. In parallel fashion, more spending by hospital interest groups increases the probability that a state allows nurse practitioners and physician assistants to practice with more autonomy.

Graddy (1991) also considers the influence of healthcare-service provider interest groups on occupational licensing regulations in the US states. She examines such regulations for a variety of healthcare occupations ranging from dieticians to physician assistants. Graddy reports evidence for the importance of both interest groups and public health concerns in driving such regulations. Smaller, more geographically concentrated healthcare occupations facing more intense pressure from competitors are more successful in acquiring more stringent licensing regulations. So, however, are healthcare occupations whose services involve greater risk, such as midwifery, where consumer safety is of greater concern.

Closely related to healthcare occupational licensing are "commercial practice regulations" for healthcare service providers. Such regulations are created by US state licensing boards and enforced by state governments. Optometry, for example, is subject to commercial practice regulations. Those regulations may prohibit optometrists from accepting jobs in unlicensed firms such as optometry chain stores, bar optometrists from sharing offices with unrelated healthcare-service providers, cap multi-office ownership by any single optometrist, and revoke licenses from optometrists practicing under a name other than their own, e.g., a tradename associated with an optometry chain store.

Haas-Wilson (1989) studies optometry commercial practice regulations in the US states. She argues that self-employed optometrists exploit them as a device to secure rents. Optometry commercial practice regulations impose costs on optometry service providers asymmetrically. While those regulations make it more costly for selfemployed ("professional") optometrists to work for ("nonprofessional") optometry chain stores, they make it more costly for optometry chain stores to exist at all. In an unregulated market, self-employed optometrists must compete with optometry chain stores, whose services are less expensive. But by raising chain stores' costs disproportionately, optometry commercial practice regulations disproportionately deter chainstore occupational entry. Haas-Wilson finds that such regulations are associated with lower rates of optometry chain store entry but have no effect on self-employed optometrist entry.

Benham (1972) considers US state regulations on advertising eyeglasses and eye examinations. The alleged aim of such regulations is to promote consumer welfare by preventing "deceptive" and "fraudulent" practices such as "price advertising". That goal is unlikely to be the regulations' actual aim, however, since price advertising per se is neither deceptive nor fraudulent. Bentham suggests that restrictions on advertising eyeglasses and eye examinations are instead driven by self-employed optometrists who seek them to limit competition from lower-priced competitors: optometry chain stores. Benham finds that states banning price advertising for eyeglasses and exams tend to have higher average prices but not services of higher quality. Furthermore, optometry chain stores tend to have smaller market shares in such states. Benham interprets those findings as evidence that restrictions on advertising eyeglasses and eye examinations reflect rent seeking by self-employed optometrists. 


\subsection{Mental health}

Public health regulation addresses mental as well as physical health. Well-organized interest groups may therefore also take advantage of regulations that address mental health to redistribute wealth to their members. Geloso and March (2020) study the history of US state regulations governing the institutionalization of the mentally ill. Between 1870 and 1910, the share of America's population committed to mental institutions nearly tripled. The public interest approach to government sees that increase as reflecting greater citizen demand for institutionalization of the mentally ill attendant to an increased prevalence of mental illness. According to Geloso and March, however, the increase reflected rent seeking by psychiatrists who seized an opportunity to organize and influence state governments after the Civil War, when state governments' regulatory powers expanded substantially.

Before the Civil War, local almshouses that cared for the poor and physically disabled also cared for persons considered mentally ill. The care they provided was not medical, for almshouse caretakers were not medical professionals. After the Civil War ended, mentally ill persons in almshouses increasingly were transferred to newly created public asylums administrated and serviced by professional psychiatrists. The state laws that compelled the transfer, Geloso and March argue, were lobbied for by psychiatrist interest groups, whose members sought to take the mental healthcare business out of the hands of almshouses and put it into their own. Psychiatrists also lobbied for the creation of new public asylums and for additional state public asylum funding. The culmination of their rent-seeking strategy, however, was successful lobbying for state laws that made it easier to commit individuals with mental illnesses without consent. Such laws not only ensured additional demand for care of the mentally ill but, specifically, additional demand for such care as provided by psychiatrists employed by public hospitals and asylums - the institutional recipients of individuals committed involuntarily for mental illness.

\subsection{Human organs}

The sale of human organs in the United States is prohibited by the National Organ Transplant Act of 1984. Advocates of that act, which historically have included the American Medical Association, the American Society of Transplantation, the American Society of Transplant Surgeons, and the National Kidney Foundation, contend that it promotes organ access for the poor, protects the poor against "coerced" organ sales, and improves the quality of organs available for transplant. Infamously, however, by imposing a legal price ceiling of $\$ 0$ on organs, the ban contributes to organ shortages.

Kaserman and Barnett (1991) develop a model that explains interest group support for the National Organ Transplant Act (see also Barnett et al. 1993; Blair \& Kaserman, 1991). They explain that by creating an organ shortage, the organ-sales ban may create rents for the members of medical interest groups. The supply of available organs limits the supply of transplants. And a restricted supply of transplants raises the price of transplants, which, unlike the price of organs themselves, does not face a legal ceiling. Hence, the suppliers of (non-organ) transplant inputs, such as transplant surgeons and transplant centers, earn rents when the maximum legal price that may be paid for organs is zero.

The regulation-created organ shortage in effect enforces transplant-input supplier cartels by enforcing restrictions on the number of transplants that can be performed. The resulting rents, Kaserman and Barnett argue, may motivate medical interest groups, 
whose members consist of such suppliers, to encourage lawmakers to make and preserve laws that ban organ sales. The suppliers of inputs to organ transplants are not the only potential beneficiaries of the organ-sales ban. Suppliers of transplant substitutes may benefit from the ban, too, for example the providers of kidney dialysis treatments. A restricted supply of kidney transplants increases the demand for dialysis treatments. That creates rents for dialysis-treatment providers, who thus also have an incentive to encourage lawmakers to make and preserve legislation that bans organ sales.

\subsection{AIDS}

Forty years ago the United States recognized AIDS as an epidemic. AIDS thereby became a target of US public health policy, and that policy became a target of interestgroup influence. Ohsfeldt and Gohmann (1992) study the regulation of AIDS insurance underwriting practices in the US states. In the 1980s, some states prohibited private insurance companies from asking applicants about past HIV tests, from requiring applicants to submit an HIV antibody test, from questioning applicants about their sexual orientation, and/or required insurance companies to cover AIDS treatments. Insurance companies have an incentive to lobby against such regulations. Categorical risk indicators, for instance, facilitate identification of individuals actuarially likely to contract AIDS, and failure to identify such individuals prevents insurance companies from charging them actuarially fair premiums. Individuals at risk of AIDS, in contrast, have an incentive to lobby in favor of underwriting restrictions. If those individuals cannot be identified by insurance underwriters, for example, they cannot be charged higher premiums. Ohsfeldt and Gohmann find that AIDS insurance underwriting regulations were less likely to be adopted in states with politically stronger insurance industries and were more likely to be adopted in states where AIDS was more prevalent.

\section{Private interests and public health resource allocation}

Governments are major (re-)distributors of health resources, from providing health insurance to funding medical research to allocating vaccines. The public interest approach to government suggests that such resources are distributed optimally from the perspective of social welfare: political actors allocate public health resources where their social value (accounting for equity considerations) is maximized. The interest group approach to government, in contrast, suggests that public health resources are distributed optimally from the perspective of the distributors' private welfare: political actors allocate such resources where their value to political actors is maximized. Often the latter reflects the allocation of public health resources desired by well-organized interest groups. We survey public-choice relevant scholarship that addresses the allocation of public health resources below. 


\subsection{Public health insurance}

Public health insurance programs are among the largest categories of government expenditure. ${ }^{17}$ The healthcare services such programs cover, whom those programs cover, and other coverage details thus offer valuable sources of rents to healthcare interest groups. Healthcare interest groups correspondingly have powerful incentives to lobby for public health insurance arrangements that steer public health insurance program spending toward their members. Mendoza (2015), for instance, investigates the essential health benefits mandate of America's Affordable Care Act of 2010 (ACA). That law, known colloquially as Obamacare, required plans in the individual and small-group insurance markets to cover "essential health benefits". Which health benefits are "essential" is not obvious, and which benefits are deemed essential affects the demand for the services of different healthcare providers. Healthcare provider interest groups thus have a strong incentive to see that the services they provide are designated as essential. The result for the ACA, Mendoza argues, was an essential health benefits definition that reflected interest-group rent seeking. Lobbying by the American Chiropractic Association and the American Society of Plastic Surgeons, for example, resulted in chiropractic and prosthetic care being designated as essential.

Spithoven (2016) likewise studies the ACA. He argues that its spending provisions were driven by rent-seeking medical interest groups whose support was required to avoid scuttling healthcare reform. Hence the ACA, for example, increased Medicare payments to socalled "outlier" physicians who bill especially numerous services to Medicare, maintained Medicare reimbursement rates for other physicians that were planned for reduction, and did not include a "public option" that would have threatened those payments. The ACA's provisions were included at the behest of and consequent to lobbying by the American Medical Association.

Camobreco (1996) examines optional Medicaid spending in the US states. ${ }^{18}$ Under Medicaid, the federal government requires states to cover certain health services for individuals who receive assistance from two programs: Aid to Families with Dependent Children (AFDC) and Supplemental Security Income (SSI). Physicians primarily serve AFDC recipients, although many physicians do not participate in Medicaid. Nursing homes primarily serve SSI recipients and depend heavily on Medicaid spending for income. Hospitals serve recipients of both programs. States, however, may cover additional health services beyond those required by federal law and may cover additional individuals.

To explore sources of variation in optional Medicaid spending across states, Camobreco considers a "pluralist model" according to which all groups interested in Medicaid spending-whether they are organized well or poorly-have equal potential influence over that spending, and a "plural elitist" model according to which only small or large but wellorganized groups-such as those representing physicians, hospitals, and nursing homesmay influence Medicaid spending. ${ }^{19}$ Camobreco finds support for the plural elitist model.

\footnotetext{
17 Tullock (1983) considers the likely consequences of moving from a public health insurance system like that observed in the United States, where government provides health insurance to the elderly and poor, to a public health insurance system like that observed in Europe, where governments provides health insurance to all.

18 Medicaid is financed jointly by the federal and state governments, with every dollar appropriated by the latter matched by at least 50 cents from the former.

19 Barrilleaux and Miller (1988) find that states with more interest group diversity spend more on Medicaid but that states with a larger supply of physicians spend less. They attribute this finding to the idea that when
} 
Stronger hospital interest groups are associated with more optional SSI-category Medicaid spending. And stronger nursing home interest groups are associated with more optional SSI- and AFDC-category Medicaid spending.

Kousser (2002) also studies optional state Medicaid spending. He finds that the strength of physician, senior citizen, and medical industry interest groups is positively related to optional spending, as is Democrat control of the state legislature. ${ }^{20}$ Public opinion, in contrast, is unrelated to optional state Medicaid spending. Similarly, Grogan (1994) investigates optional state Medicaid policies with respect to recipient eligibility and programs. She finds that the strength of healthcare interest groups is positively related to policies that more generously define categories of eligible recipients and offer more generous programs. Pracht and Moore (2003) consider state Medicaid drug reimbursements to pharmacies. Pharmacies benefit from more generous reimbursement rates in the form of lower ingredient and dispensing costs. Pracht and Moore find that the share of state pharmacists who are members of the American Pharmaceutical Association is strongly and positively related to state reimbursement rates.

Cooper et al. (2020) study America's Medicare Modernization Act of 2003. That law, which expanded Medicare to cover prescription drugs for seniors, reflected the largest expansion of the program in Medicare's history. Its sweeping nature, however, made finding lawmaker support for enacting the law difficult. Reelection motives incentivize lawmakers to pass legislation that confers direct benefits on their constituents, for that is the kind of legislation for which lawmakers can claim credit. In general, lawmakers cannot plausibly claim credit for sweeping legislation like the Medicare Modernization Act. Few lawmakers therefore have a strong interest in supporting such legislation. If, however, sweeping legislation is modified to include pork that targets the constituents of otherwise disinterested lawmakers, the support of those lawmakers for sweeping legislation may be secured.

Cooper et al. argue that Olsonian "selective benefits" for lawmakers propelled the passage of the Medicare Modernization Act. The act secured requisite legislative support only after the addition of Sect. 508, a provision that permitted hospitals to apply for larger Medicare payments. Cooper et al. find that hospitals represented by Members of Congress who voted for the Medicare Modernization Act were more likely to receive more generous Medicare payments and tended to receive much larger payments than hospitals represented by their colleagues who voted against the act. The addition of Sect. 508 thus constituted provision of the healthcare pork necessary to motivate sufficient "yea" votes. That pork, moreover, took on a life of its own. The payment increases enabled by Sect. 508 were meant to expire three years after enactment. Before they could do so, however, the hospitals that received them formed the Sect. 508 Hospital Coalition. Through large campaign contributions to relevant congressmen, the newly created interest group successfully secured the extension of supernormal payments.

Tollison and Wagner (1991) suggest that physician support for Medicare and Medicaid may reflect physicians' concern for their pocketbooks rather than for the elderly and poor. By subsidizing healthcare, those programs increase the demand for physicians' services. Hence, when physicians' services are produced under conditions of rising supply price,

Footnote 19 (continued)

physicians are more numerous, their interests are more fragmented, and thus their organization is less unified.

20 Sobel (2014) also finds that party control affects decisions to expand state Medicaid eligibilities. 
Medicare and Medicaid generate rents for physicians. More generally, the same logic suggests that physicians have a financial interest in any public health program that makes death more medically intensive. Consider, for example, a public health program that increases the population's longevity. Insofar as the demand for physicians' services increases with age, such a program increases that demand, generating rents for physicians. One implication of this line of reasoning is that successful rent seeking by the American Medical Association may result in "excess" longevity.

Mobarak et al. (2011) study political influence on the allocation of federal and state health resources to county governments in Brazil. Brazil's Unified and Decentralized Health Care System subsidizes healthcare for citizens. Under that system, most countylevel health resources come from state and federal government transfers. Mobarak et al. do not consider the role of private interest groups in affecting the allocation of health resources to Brazilian counties. Rather, they consider how the popularity of county mayors and their political alignment with state governors may affect that allocation. Mobarak et al. (2011, p. 745) rely on mayoral popularity and political alignment as proxies for the influence of political "clientelism and patronage" on health resource allocation. Mobarak et al. find that counties with more popular mayors and counties whose mayors are from the same party as their states' governors receive larger health resource transfers.

\subsection{National Institutes of Health}

The National Institutes of Health (NIH) is the primary government agency responsible for biomedical and health-related research in the United States. The NIH funds research conducted by successful grant applicants such as universities, disease research centers, and businesses. Health-related interest groups may seek to channel these funds to their members and, for that purpose, may lobby legislators who have influence over the NIH's budget.

Hegde (2009), for example, observes that the NIH's budget is appropriated by the House Appropriations Subcommittee for Labor, Health and Human Services, Education and Related Agencies. To protect NIH's independence, its budgetary appropriations are not earmarked for specific investigators. Hegde, however, argues that health-related interest groups shape NIH budget appropriations nonetheless. Unable to earmark NIH support explicitly for specific research performers in their constituencies, budget-appropriating legislators steer support to those performers in the form of "soft earmarks". Such earmarks encourage the NIH to use appropriations to fund the biomedical research fields and projects in which the researchers in budget-appropriating legislators' constituencies are engaged. Hegde finds that researchers in the states of appropriations' subcommittee members receive more NIH research funding than researchers at unrepresented institutions. In a related paper, Hegde and Sampat (2015) examine interest group lobbying for soft earmarks in NIH budget appropriations. They find that more active lobbying by disease-specific interest groups is associated with larger numbers of soft earmarks for the diseases with which those interest groups are concerned.

Ward and Dranove (1995) study NIH- and pharmaceutical company-funded drug research. Some categories of drug research consider diseases that are very debilitating but affect few people, such as Parkinson's. Other categories of research consider health conditions that are not debilitating but are quite prevalent, such as baldness. Ward and Dranove find that whereas pharmaceutical firms allocate more research funding to categories of illness that are more debilitating and, still more so, to those that are more prevalent, the NIH allocates more research funding in the opposite direction. 
Ward and Dranove interpret their findings as suggestive of interest group influence on NIH research funding. Pharmaceutical firms allocate their research funding across disease categories to maximize profit, which, if the market is not distorted, corresponds to the allocation of research funding that is most valuable to consumers. Deviations from that allocation pattern in NIH research funding, which focuses on severe but relatively rare illnesses, may therefore indicate capture by organizations devoted to those illnesses. Even if market distortions make pharmaceutical companies' research allocations an inappropriate allocative benchmark, insofar as NIH research funding seeks to serve the public interest, one would expect it to respond to both disease severity and prevalence. Yet Ward and Dranove's results suggest that it does not.

Batinti (2016) investigates the executive branch of government as a source of political influence on the allocation of NIH research funding. The president is involved in the design of the NIH's budget proposals and in defining the NIH's priorities before a proposed budget becomes a formal appropriations bill. The president also can affect the NIH's budget by exercising (or not exercising) his veto power over bills that would affect the NIH's budget. Those authorities, Batinti argues, enable the president to steer the allocation of NIH research funds, and the president's interest in his (or his party's) reelection incentivizes him to steer NIH research funds to politically important states. Batinti finds that recipients of NIH funding in presidential election swing states receive more funding than recipients of NIH funding in other states.

\subsection{Social preference manipulation}

Clark (1997) develops a model wherein competing interest groups vie for public health resources. His analysis is purely theoretical and departs sharply from the interest group approach to government in that it assumes a benevolent government. In Clark's model, a central planner allocates health resources across groups by maximizing a social welfare function weighted by citizens' attitudes toward those groups. What is of interest (to us, at least) in Clark's paper is the idea that interest groups can influence the allocation of public health resources even when government is benevolent. By investing in propaganda, health advocacy groups can improve citizens' attitudes towards the groups' favored health issues. In doing so, interest groups raise their odds of capturing larger shares of public health resources. Such investments may take the form of advertising awareness of a disease, advertising its prevalence or the severity of its consequences, or providing the public with information about the disease. Such information and advertising need not be accurate, and misinformation can be a valuable tool for shaping social preferences in an interest group's favor. Tollison and Wagner (1991), for instance, suggest that cancer interest groups may exaggerate the risk and incidence of cancer for that purpose.

\subsection{Tobacco funds}

Governments in the United States spend money to address and combat tobacco use. The extent and allocation of that spending matters to both tobacco and healthcare provider interest groups, whose members the spending may harm or benefit. Tobacco and healthservice provider interest groups therefore may lobby to influence the level and allocation of antitobacco spending. Stevenson and Shughart (2006), for example, study the allocation of funds to US states collected from major tobacco companies under the 1998 Master Settlement Agreement (MSA). That agreement resolved lawsuits with the attorneys general of 46 
states seeking the recovery of public expenditures on treating smoking-related diseases. ${ }^{21}$ Some states, however, received substantially larger settlement payments than would be suggested by their expenditures on treating such diseases while other states received substantially less.

Stevenson and Shughart argue that the pattern of MSA settlement allocations reflects rent seeking by health-related interest groups. Nonprofit health advocacy groups and healthcare providers such as doctors and nurses stand to benefit from larger settlement allocations, which finance smoking-related medical research, smoking-cessation clinics, and smoking-prevention programs that health advocacy groups and health-service providers supply. Stevenson and Shughart find that states where these interest groups are more prevalent received larger MSA allocations.

Hoffer and Pellillo (2012) consider US state tobacco-control funds, which finance antitobacco programs and education. Tobacco-producer interest groups have an incentive to lobby against such spending, whose purpose is to reduce the demand for their products. Hoffer and Pellillo find that spending on tobacco control is lower in states where more tobacco is produced and where tobacco interest groups contribute more to the campaigns of state legislators.

\subsection{Vaccines}

Vaccines are of great value amidst an epidemic or pandemic. And when government controls vaccine distribution, legislators who can influence vaccine allocations have strong incentives to appropriate part of that value for themselves. One way they may do so is by allocating vaccines in a manner that privileges their constituents, something for which the legislators can claim credit. Ryan (2014) studies the US government's allocation of the H1N1-virus vaccine following the unexpected spread of the swine flu in 2009. Vaccine allocation was the responsibility of Department of Health and Human Services. Political oversight of the department's vaccine distribution fell to the Committee on Energy and Commerce (in the House) and to the Committee on Health, Education, Labor, and Pensions (in the Senate). Congressional dominance theory (Weingast \& Moran, 1983) an extension of the interest group approach to government to encompass the control of bureaucrats - suggests that specialized congressional committees like those mentioned above will use their budgetary and oversight responsibilities to ensure that bureaucrats use their authorities in ways that congressional committee members desire: in a manner that serves the committee members' interests.

Ryan finds support for that theory in the allocation of the H1N1 vaccine. States with Democratic representatives on the Committee on Energy and Commerce received disproportionately large allocations of the vaccine relative to states without committee representatives. Initial distributions of the vaccine were not allocated to states with larger at-risk populations (pregnant women, young adults, and young children). Furthermore, once the weekly distribution of vaccines increased sharply, the influence of committee membership on vaccine allocation declined sharply. As the value of being allocated additional vaccine fell, committee members' interest in influencing its allocation did too.

Barrett (2006) studies the delayed-and nearly failed-global eradication of smallpox. In 1959 the World Health Assembly endorsed a resolution to eliminate smallpox in

${ }^{21}$ Wagner $(1999,2004)$ highlights the interest of lawyers in tobacco-related litigation. 
developing countries where the disease remained endemic. The eradication program's principal financiers were governments in developed countries where the smallpox vaccine already had eliminated the disease. Not until 1979, however, was smallpox eradicated globally. Barrett attributes the 20-year delay to the absence of rent-seeking interest groups. His analysis thus highlights the importance of those groups to public health resource allocation in a rather different way than the other studies considered in this section.

Contributor countries, though free from smallpox, had to vaccinate their domestic populations against the disease continually, which could still spread to them from developing countries. The contribution required to eliminate smallpox in developing countries, Barrett points out, was dwarfed by the cost of continued vaccination in a contributor country. Hence, a contributor country would benefit on net by contributing appropriately to global eradication. Contributor countries, however, faced a free-rider problem: each wanted the others to make the required contribution so that it could enjoy the benefits of global eradication at no cost to its own taxpayers. The problem could have been overcome if in contributor countries interest groups had mobilized that would gain by and thus lobby for the smallpox policy. Yet that did not occur, according to Barrett, because the market for the smallpox vaccine was highly competitive: smallpox vaccine manufacturers therefore did not anticipate appreciable rents (or their loss) from smallpox eradication. As a result, no interest group lobbied for (or against) eradication in contributing countries, delaying global smallpox eradication for two decades.

\subsection{AIDS}

In fiscal year 2019, the US federal government allocated more than $\$ 28$ billion to domestic AIDS services, research, and programs (HIV.gov, 2020). Three-and-a half billion dollars of America's domestic AIDS budget is allocated to research and prevention alone. Wellorganized AIDS interest groups may be responsible for the fact that AIDS receives such large public health resource allocations. Philipson and Posner (1993) argue that government-funded AIDS research, subsidized HIV testing, and AIDS education programs in the United States reflect the efforts of AIDS interest groups to redistribute wealth from the mass of taxpayers to their members. The first part of Philipson and Posner's argument contends that the observed magnitude of AIDS interventions cannot be justified on efficiency grounds, an argument we return to in Sect. 6.4. Of interest here is the second part of their argument, according to which the two major populations that stand to benefit significantly from public spending on AIDS-homosexual males, along with medical professionals and drug producers-satisfy the conditions for influential interest groups: their members are concentrated geographically, modest in number, tend to be well educated, and tend to have above-average incomes. Homosexual males, according to Philipson and Posner, seek public spending for AIDS because they constitute the population at high risk of contracting AIDS. Medical professionals and drug producers seek such spending because it increases the demand for their services and subsidizes their inputs.

\section{Perverse effects of public health policies}

Insofar as public health policies are driven by interest-group rent seeking rather than by concern for the public's welfare, it should not be surprising that the results of those policies inure to the benefit of interest groups rather than to the public at large. What interest 
groups desire does not always diverge from what benefits society. Often, however, it does, and when that is the case, policies that redistribute wealth to interest groups may produce results that are not merely inferior from the standpoint of society but are in fact opposite of the goals ostensibly sought by the policies in question. Public health policies ostensibly seek to promote healthcare consumer welfare. Perverse effects therefore manifest in this context when such policies undermine healthcare consumers' welfare. We survey publicchoice relevant scholarship that points to ineffective or perverse consequences of public health policies below. ${ }^{22}$

\subsection{Drugs}

The stated goal of pharmaceutical regulations is to promote drug-consumer welfare. The effects of some pharmaceutical regulations, however, seem rather to have been the reverse. Peltzman (1987a, 1987b), for instance, studies mandatory prescriptions that require consumers to obtain the permission of a physician before they can purchase and take certain drugs. He considers such regulations in the United States, where the FDA introduced mandatory prescriptions for certain nonnarcotic drugs following passage of the Food, Drug, and Cosmetics Act of 1938, and in a sample of middle-income countries whose mandatory prescription regulations are enforced to varying extents. ${ }^{23}$

The net effect of mandatory prescription regulations on drug-consumer welfare, Peltzman argues, is uncertain theoretically. On the one hand, some consumers who may errantly have self-treated with dangerous drugs if no prescription were required are prevented from doing so, reducing the risk to drug consumers' health. On the other hand, some consumers may now seek and obtain drugs from physicians that are more dangerous than the drugs that consumers would have been willing to take if they were self-treating, creating a moral hazard that increases the risk to drug consumers' health. Peltzman finds that in the United States mandatory prescription regulations imposed by the Food, Drug, and Cosmetics Act did not reduce poisoning deaths and may have increased them. In his international sample, Peltzman is able to examine deaths from infectious disease as well. There he finds that more strictly enforced mandatory prescription regulations are unrelated to infectious disease mortality and, as for the United States, are associated with elevated poisoning mortality.

In another paper, Peltzman (1973) studies the 1962 Kefauver-Harris Amendments to the Food, Drug, and Cosmetics Act. Those amendments required manufacturers to prove to the FDA the efficacy of new drugs before they could go on the market-so-called premarket review. Peltzman observes that premarket review has two effects. One is to prevent

\footnotetext{
${ }^{22}$ Effects of this nature commonly are called "unintended consequences" and sometimes that appellation may be correct. We prefer, however, to call them "perverse effects" since the interest group approach to government suggests that they often are intended-or, if not exactly intended, are at least expected. When, for instance, hospital and physician groups lobby against legalizing organ sales, their goal—according to interest group approach to government-is to preserve the rents they enjoy because of the organ shortages the ban creates. The rents these interest groups' members thereby earn certainly are intended, and the shortage, which is responsible for those rents, is intended too. The shortage, however, also is responsible for premature deaths. Those deaths are not "intended" in the sense of being sought as an end (like the rents) or as means necessary to the end (like the shortage). But it is hard to imagine that the deaths are not expected.

23 Temin (1979) studies the origin of compulsory nonnarcotic drug prescriptions in the United States. His analysis casts doubt on the public-interest account, according to which drug-consumer safety required physician approval for various nonnarcotic drugs.
} 
ineffective drugs from reaching the market, which benefits drug consumers. The other effect is to prevent unproven but effective drugs from reaching the market, which harms drug consumers. The latter effect occurs because the FDA does not approve all effective drugs (its review process is fallible), because FDA approval is a lengthy process, and because the cost of proving efficacy to the FDA discourages drug innovation and thus prevents some effective drugs from being introduced. Peltzman estimates the sizes of these effects and finds that the net result of the Kefauver-Harris Amendments was to reduce drug-consumer welfare.

Sobel (2002) considers the FDA's "beyond-a-placebo" regulation according to which manufacturers must prove new drugs to be more effective than a placebo to secure premarket approval. That standard ostensibly is applied to promote consumer health by preventing the sale of fraudulent, impotent medicaments. Sobel, however, argues that the FDA beyond-a-placebo test is in fact detrimental to consumer health. Placebo effects are real: "a placebo has a 30-40\% probability of being effective for almost any disorder" (quoted in Sobel, 2002, p. 474). Indeed, if placebo effects were not real, it would not make sense for the FDA to require that new drugs demonstrate their effectiveness beyond that of a placebo. There is, moreover, no fraud if a placebo treatment's ingredients and the therapeutic uses for which it has proven effective are indicated accurately. Placebos contain no harmful ingredients, produce no side effects, and are far cheaper than non-placebos. The FDA's regulation denies consumers the ability to buy proven placebo treatments when they sometimes are the only, or the only safe, treatments available. As such, Sobel contends, the beyond-a-placebo regulation undermines rather than promotes consumer health.

Schaumans and Verboven (2008) consider regulations that restrict the number of pharmacies on a geographic basis in Belgium. The alleged purpose of the regulations is to improve consumers' access to pharmacies in regions of the country where pharmaceutical sales are less profitable. Yet Schaumans and Verboven find that in the absence of entry regulations, the number of markets with no pharmacy would fall. This evidence suggests that Belgium's pharmacy entry regulations have an effect opposite to that ostensibly intended.

\subsection{Alcohol}

Gant and Ekelund (1997) study Title XI of America's Omnibus Budget Reconciliation Act of 1990. That title increased excise taxes on wine, liquor, and beer. One of its purported aims was to reduce alcohol-consumption externalities such as drunk driving. But Gant and Ekelund argue that its effect actually may be the reverse. The percentage increase in Title XI's excise tax on wine was much larger than it was on liquor and beer, with which wine is a substitute. The tax increase thus induced substitution away from wine and, as Gant and Ekelund show, mostly into beer. Research suggests that wine drinkers are more responsible alcohol consumers than beer drinkers, who are much more likely to drive drunk. That observation, Gant and Ekelund maintain, implies that the effect of the Title XI excise tax increase may be to increase alcohol-consumption externalities rather than to reduce them.

\subsection{Tobacco}

Among the avowed aims of tobacco regulation is the promotion of consumer health by reducing cigarette consumption. Schneider et al. (1981), however, contend that in the case of the US Public Health Cigarette Smoking Act of 1970, the effect was the opposite. That law prohibited cigarette advertising on television and radio. Schneider et al. observe that 
the advertising ban has two effects. One is to reduce the demand for cigarettes, which reduces the quantity of cigarettes consumed. But the other effect is to increase the supply of cigarettes by reducing the fixed cost (advertising) of supplying them, which induces new tobacco firms to enter the market and increases the quantity of cigarettes consumed. Schneider et al. argue that the latter effect dominated the former following the 1970 advertising ban, resulting in more cigarette consumption rather than less.

\subsection{Healthcare occupational licensing and commercial restrictions}

The ostensible purpose of healthcare occupational licensing and commercial restrictions is to promote consumer welfare by assuring the quality of healthcare service provision. Some public health regulations of that kind, however, seem to have reduced healthcare consumers' welfare instead. Kleiner et al. (2016), for instance, examine scope-of-practice regulations for nurse practitioners in the US states. Nurse practitioners are registered nurses who have through a master's or doctoral degree program obtained additional training in diagnosing and treating illnesses and prescribing medication. Scope-of-practice regulations restrict nurse practitioner activities vis-à-vis physicians, for example by limiting the authority of nurse practitioners to prescribe medications. Kleiner et al. find that the price of well-child visits - a service that could be provided easily by a nurse practitioner or physician-increases when states adopt scope-of-practice regulations that limit nurse practitioners' prescription-writing authority. Furthermore, the regulations do not improve the quality or safety of the healthcare services. This evidence suggests that scope-of-practice regulations reduce healthcare consumers' welfare.

Haas-Wilson (1986) investigates the effect of optometry commercial practice regulations on eyeglass-exam prices and service quality in the US states. She finds that commercial practice regulations are associated with higher optometry service prices but not higher service quality. Similar results are found by Benham (1972) and Benham and Benham (1975), who additionally find that higher prices are associated with reduced frequency of consumer use of optometry services. Optometry consumers' welfare thus seems to be reduced by such regulations.

Several older studies that examine the effect of dentist licensing regulations in the US states suggest that such regulations reduce dental-consumer welfare (see, for example, Maurizi, 1974; Shepard, 1978; Carroll \& Gaston, 1981). Kleiner and Kudrle (2000) provide a more recent study along those lines. They examine the effect of dentist licensing regulations on untreated dental deterioration. Kleiner and Kudrle observe that more stringent dentist licensing regulations have two effects, with different implications for untreated dental deterioration. On the one hand, more stringent licensing regulations assure higher dentist quality, which increases the demand for dental services. By itself, this effect would result in a higher quantity of dental services consumed and thus less untreated dental disease. On the other hand, such regulations reduce the supply of dentists, which increases the prices of dental services. By itself, that effect would result in a lower quantity of dental services consumed and thus more untreated dental deterioration. The net result of the two effects for untreated dental deterioration is an empirical question. Kleiner and Kudrle's empirical analysis finds that more stringent dental licensing regulations have no effect on untreated dental deterioration but are associated with higher dental service prices. One interpretation of these results is as follows. From the perspective of dental health outcomes, more stringent licensing is a wash. But for the privilege of that wash, dental consumers pay higher prices, which reduces dental-consumer welfare. 
Gertler and Shah (2011) examine the consequences of licensing sex workers in Ecuador. There, sex workers require a license that certifies their freedom from sexually transmissible infections (STIs). Obtaining a license requires submitting to health checkups, submitting to frequent STI testing, and testing negative for STIs. As no cure for AIDS is available, individuals who test positive for that STI are barred permanently from obtaining a sex-work license. Licensed sex workers are permitted to ply their trade in brothels, but street solicitation is illegal. The regulations are enforced by surprise police raids in brothels-to identify and punish unlicensed sex workers-and on the street-to identify and punish any sex workers at all.

The stated purpose of licensing sex workers is to prevent the spread of STIs. But Gertler and Shah argue that the actual effect on STI spread depends on which aspect of the regulations are enforced. Brothel clients demand less unprotected sex than street clients. Hence, brothel sex work does less to spread STIs than street sex work. Tougher street enforcement raises the relative cost of street sex work and thus leads some street sex workers to move to brothels, reducing the spread of STIs. More stringent brothel enforcement, however, raises the relative cost working in a brothel without a license and thus leads some unlicensed brothel workers to obtain licenses but leads others to move to the street, the latter of which increases the spread of STIs. Gertler and Shah find a perverse effect with respect to brothel enforcement: increased enforcement there is associated with higher STI infection rates.

\subsection{Mental health}

March and Geloso (2020) consider the consequences of government-funded mental healthcare in mid-century America. That funding was provided by state and federal governments to public hospitals and asylums, ostensibly for the care of the institutionalized mentally ill. Yet March and Geloso argue that the "care" public hospital and asylums often provided does not merit that appellation. Unlike private institutions for the mentally ill, whose incomes depended on payments from patients, their custodians, or philanthropic donations and which therefore had strong incentives to provide patients genuine care, public hospitals and asylums received funding from tax dollars appropriated in state budget formulas disconnected from care quality. Public hospitals and asylums therefore had strong incentives to minimize the cost of care regardless of what it meant for welfare of their mental health patients.

According to March and Geloso, the latter incentives were responsible for America's mid-century "lobotomy boom"- a common practice at public hospitals and asylums, but not at private ones, of lobotomizing mental health patients. Lobotomies are inexpensive procedures compared to genuine mental healthcare. Furthermore, by permanently rendering the patient vegetative, a lobotomy makes him much easier to manage, dramatically reducing the ongoing expense of his or her custody. Today the medical profession regards lobotomy as an ineffective and inhumane "treatment" for mental illness, obviously destructive to the patient's well-being. But March and Geloso contend that the medical profession also regarded lobotomy that way in mid-century America. The perverse incentives created by government funding of mental healthcare, however, led public hospitals and asylums to rely on lobotomies anyway, to the detriment of mental patients' health. 


\subsection{Public health insurance}

A primary alleged goal of public health insurance is to improve citizens' access to quality healthcare. The chief effect of some public health insurance regulations, however, may be to undermine citizens' access to quality healthcare. Ramseyer (2009), for example, studies public health insurance in Japan, where government provides universal health insurance and where medical care suppliers are private entities. Universal health insurance increases citizens' demand for healthcare. To prevent a dramatic increase in costs, Japan's government thus caps the prices it pays to private medical care suppliers. Ramseyer observes that medically "superfluous" services such as cosmetic surgery, which are not covered by universal care, are not subject to government price controls. The result is to draw Japan's most talented doctors away from more important areas of care into areas like cosmetic surgery, where talented doctors can earn competitive rates of return, undermining citizens' access to quality healthcare. Ramseyer finds that Tokyo's cosmetic surgeons are better trained, more talented, and earn higher incomes than other Tokyo physicians, including non-cosmetic plastic surgeons.

Propper and Van Reenen (2010) examine a related phenomenon in the context of the United Kingdom's National Health Service (NHS). ${ }^{24}$ To keep the cost of England's public health insurance system down, nurses' pay at NHS hospitals is regulated at a level that is nearly the same across the country. Wages in the private sector, in contrast, vary regionally. The result is an exodus of higher-quality nurses out of NHS hospitals in regions where private sector wages exceed regulated NHS pay scales. Propper and Van Reenen find that the result of such exodus is a deterioration in public hospital quality manifested in an increase in public hospital deaths. ${ }^{25}$

Rosenman (2011) analyzes Medicaid-type programs that support healthcare for lowerincome citizens financed by taxes on higher-income citizens. His analysis is purely theoretical but warrants brief mention here. Rosenman models wealthy people, who contribute to public healthcare subsidies but are not eligible for them if they become sick, and poor people, who do not contribute to the subsidies but collect them if they become sick. His model suggests that public health insurance programs with such features produce a moral hazard for both groups that leads to underinvestment in self-care: healthy lifestyles. The poor underinvest in healthy lifestyles because becoming sick imposes less of a cost on them given their collection of healthcare subsidies. The wealthy do so because the taxes they must pay to contribute to public healthcare subsidies for the poor reduce the marginal value of remaining healthy. Medicaid-type programs therefore may have the perverse effect of discouraging healthy living for both contributors and recipients.

\footnotetext{
24 In one of the earliest public-choice relevant studies to address issues in public health, Buchanan (1965) considers the "inconsistencies" of the NHS: the fact that under the system, health services demanded exceed health services supplied. Buchanan considered issues in public health in two other essays. In one, he considered the possibility that rapidly rising healthcare costs in the United States may reflect lexicographic consumer preferences for healthcare. There, Buchanan suggested that for the purpose of controlling healthcare costs it may be desirable to override consumer preferences through intervention (Buchanan 1994). The other essay, coauthored with C.M. Lindsay, is titled "The Organization and Financing of Medical Care in the United States" (Buchanan and Lindsay 1970). Unfortunately, we have been unable to locate a copy of that essay and thus cannot report its contents. On Buchanan as a health economist, see Pauly (2002).

25 Tullock (1995) suggests that the politically well-connected receive better treatment under the NHS than do ordinary citizens.
} 


\subsection{Diabetes}

Klick and Stratmann (2007) investigate US state laws that require private health insurance providers to cover diabetes treatments. The stated purpose of the laws is to improve the health of diabetics. But because insurer-provided care and self-care in the form of diet and exercise are substitutes, diabetes-care mandates create a moral hazard. Klick and Stratmann find that the body mass indexes (BMIs) of diabetics increase relative to nondiabetics after the adoption of diabetes-care mandates.

\subsection{Human organs}

The National Organ Transplant Act, recall, criminalizes the sale of human organs in the United States. One justification for the ban is that it helps to assure the quality of organs available for transplant and thereby improves the probability of organ transplant success (organ sellers may, like blood sellers of the past supposedly did, reflect a pool of lowerquality suppliers). ${ }^{26}$ Barnett and Kaserman (1995), however, argue that the result of the organ-sales ban may be the reverse.

A mandatory zero price for organs, as discussed above, creates rents for transplant-input suppliers such as transplant centers. Those rents in turn attract entry by new transplant centers which, given a shortage-constrained supply of high-quality organs, merely spreads a fixed supply of high-quality organs more thinly across a larger number of transplant centers. Among the effects thereby produced are several that are likely to reduce organ transplant success rates. One such effect is reduced organ quality, since to accommodate the smaller number of high-quality organs available to each transplant center, centers must resort to using lower-quality organs (for instance from cadavers). A second effect is less effective organ donor-recipient matching, since a larger number of transplant centers means a smaller patient pool for each of them. A third effect is diminished post-transplant care quality, since such care is subject to learning and each transplant center now performs fewer transplants.

\subsection{AIDS}

The ostensible purpose of subsidized AIDS testing is to reduce the spread of the disease. Philipson and Posner (1993), however, argue that it may instead increase it. Subsidized testing leads to more testing, so more people learn their HIV status. People who test positive learn that they no longer face a risk of infection. Positive testers' cost of unprotected thus sex falls to zero, leading them to prefer unprotected sex to protected sex. People who test negative learn that they continue to face a risk of infection. If negative testers knew the identities of positive testers, they therefore would insist on protected sex with positive testers. Since, however, negative testers typically do not know the identities of positive testers, often they will not insist on protected sex with positive testers, who will encourage

\footnotetext{
26 Thomas and Thomas (2018a, b) provide a public-choice analysis of US regulation of the market for blood.
} 
unprotected sex. Unprotected sex thus may rise in the population consequent to subsidized AIDS testing, increasing the spread of AIDS. ${ }^{27}$

\section{Rebutting healthcare market failures}

The foregoing sections considered studies that address issues in public health using the interest group approach to government or containing arguments or findings that are consistent with that approach. Our sections were organized around the three themes enumerated in this paper's introduction: (1) Public health regulations often are driven by private interests, not public ones. (2) The allocation of public health resources often reflects private interests, not public ones. (3) Public health policies may have perverse effects, undermining instead of promoting healthcare consumers' welfare. In this section we consider a smaller, "sister" strand of literature that, while not concerned directly with the interest group approach to government, reflects a complementary theme: the non-failure of healthcare-related markets that are alleged to fail. Whereas the work surveyed above highlights the importance of interest groups in shaping public health interventions purportedly necessitated by healthcare-market failures and considers the perverse effects those interventions may create, the work surveyed below challenges the market-failure premise that motivates public health interventions according to the public interest approach to government.

\subsection{Drugs}

Leeson (2020) challenges the conventional wisdom according to which the market for patent medicine in Industrial Revolution England was a failure rife with producer deception. That market, he argues, was in fact honest and well-functioning. The view that it was not results from judging a historical medical market from the perspective of modern medical knowledge to which historical market participants did not have access. What looks to modern eyes like fraud thus was sincere dealing in a "normal" market where, medical science now informs us, the medical information that buyers and sellers had was inaccurate.

Consider, for example, the modern perception that Industrial Revolution English patent medicines did not contain actual medicine, only useless or dangerous ingredients. Leeson argues that the ingredients patent medicines contained, while useless or dangerous from the perspective of modern medical science, were medicinal from the perspective of Industrial Revolution English medical science and, thus, also were found in the medicines that medical professionals then dispensed. Or consider the modern perception that Industrial Revolution English patent medicines were marketed fraudulently as panaceas. Leeson argues that the vast majority of patent medicines were in fact marketed as treatments for only a few categories of disease, whose constituent health conditions, while unrelated from the perspective of modern medical science, were related from the perspective of Industrial Revolution English medical science, which considered them treatable by the same medicine.

March (2017) challenges the justification for FDA risk-management regulation of the drug isotretinoin (Accutane) according to which private regulation of that drug was

\footnotetext{
27 Philipson and Posner also argue that the public provision of free condoms may, by creating a moral hazard, increase rather than reduce the spread of AIDS-the provision's avowed aim.
} 
ineffective. Isotretinoin is beneficial for treating acne. It is, however, dangerous to fetuses and therefore should not be used by pregnant women. Managing the drug's risk effectively thus requires enabling patient access when physicians believe the drug to be beneficial while at the same time preventing access by pregnant patients. Between 1987 and 1999, the task of managing isotretinoin risk was undertaken privately by the drug's manufacturer, which created and enforced regulations that physicians had to follow before prescribing the drug and that female patients had to follow to receive the drug to ensure that they were not and would not become pregnant. In 2001 the FDA assumed risk management regulation from the drug manufacturer on the grounds that FDA regulation-to be based on more stringent requirements-would be more effective. March finds that it was not. Under private regulation, the average number of patient pregnancies was lower than under FDA regulation. And under private regulation, patient drug access (total prescriptions) increased, while under FDA regulation patient drug access declined.

\subsection{Tobacco}

Tollison and Wagner (1992) challenge the justification for tobacco regulations according to which tobacco consumption generates external costs (see also Shughart \& Tollison, 1986). The principal costs of smoking are of three kinds: foregone output owing to smoker sickness or death, medical care for smokers who may become sick or diseased more often than nonsmokers, and ambient pollution - the fact that many nonsmokers object to being around smoke. Tollison and Wagner argue that each of these costs is (or could readily be) internalized in markets. ${ }^{28}$

The cost of output foregone because of smoker sickness or death is internalized by smokers in the form of lower wages. The cost of medical care for smokers when health insurance is private is internalized by smokers in the form of higher premiums. The situation is different when health insurance is provided publicly. But since smokers tend to die younger than nonsmokers, their cost to public health insurance systems may in fact be lower than the cost of nonsmokers. ${ }^{29}$ The cost of pollution produced by smokers is internalized by private space owners, whose profit maximization calculus leads them to regulate smoking in their spaces in a manner that maximizes the space's value to consumers and employees. Hence the existence of separate smoking and nonsmoking sections in restaurants prior to government smoking bans, the existence of completely nonsmoking retail establishments, and the use of air filters in some workplaces that permitted smoking. ${ }^{30}$

\subsection{Sewers and water}

Anderson (1990) challenges the justification for government provision of sewer services according to which sewers, because they are capital intensive, enjoy enormous scale economies that would result in natural monopolies if provision were left to the market. Anderson observes that in late nineteenth-century America, private sewer companies were common

\footnotetext{
28 Wagner (1997) offers analogous arguments with respect to alcohol.

29 Tullock (1997), too, suggests that smokers are less costly to public health insurance systems because they die younger and because smoking-related diseases are relatively cheap to treat.

30 Boyes and Marlow (1996) report evidence of internalizing behavior among restaurants in California.
} 
and competed without problem. Competitive private sewer services were displaced by monopoly services only when municipal authorities asserted a monopoly.

Troesken (1999) challenges the justification for public waterworks according to which private water suppliers will underinvest in water quality (a "public good"). He observes that in late nineteenth- and early twentieth-century America, water commonly was supplied by private companies, which had incentives to attend to water quality. ${ }^{31}$ Consumers could and did sue private water companies for damages arising from, for example, typhoid epidemics since a company's failure to filter the water it supplied could spread the disease. Troesken finds that private water companies in late nineteenth- and early twentieth-century America invested in water filters more often than public utilities did, not less.

\subsection{Infectious disease}

Anderson (1990) challenges the justification for interventions ostensibly aimed at reducing deaths from infectious disease. According to that justification, markets will not reduce deaths from infectious disease significantly because actions that would reduce such deaths entail positive externalities. Anderson suggests that the well-documented decline in Western mortality rates between the Industrial Revolution and the early part of the twentieth century-mostly the result of fewer deaths from infectious disease-may be attributable primarily not to public health interventions, which occurred over the same period, but to improving economic development under capitalism.

As incomes grew under capitalism, so did the quality of the food that people consumed, and better nutrition reduced mortality from infectious diseases. As coal, gas, and electricity prices fell, average home temperatures in the winter rose, reducing the prevalence of contagious diseases that spread more easily at cold temperatures. As the germ theory of disease became accepted, surgical instruments were sterilized reducing infection. And as cars replaced horses for transportation, horse manure in the streets - an attraction for disease-carrying flies-disappeared. The decline in mortality rates attendant to these developments, Anderson argues, reflected economic progress driven by markets. ${ }^{32}$

Philipson and Posner (1993) challenge the justification for substantial AIDS interventions according to which AIDS creates substantial external costs. The external costs of AIDS, they argue, are in fact modest. That is so for two reasons. First, barring rape or other coercion, one contracts AIDS only as the result of consensual sexual interaction, whose expected benefits must exceed the expected costs for both parties or there would be no interaction. The risk of contracting AIDS therefore is a risk borne voluntarily, with the result that its consequence-which in some cases will be to contract AIDS - is internalized.

Second, while the foregoing logic does not mean that AIDS generates no external costs, the cheapness of condoms suggests that those costs are modest. People who engage in unprotected sex increase not only their own risk of contracting AIDS, a cost that is internalized, but by doing so contribute probabilistically to the prevalence of the disease and therefore increase the risk that third parties may contract AIDS, a cost that is externalized. The latter cost, however, is limited by the cheapest means of avoiding AIDS, for that is the

\footnotetext{
31 Anderson (1990) also touches on water supply by private companies in nineteenth-century America.

32 Troesken (1999) suggests that water consumers in late nineteenth- and early twentieth-century America may have been the least-cost avoiders of typhoid. Consumers prevented the spread of typhoid by boiling their water, washing their hands, and adopting other sanitation practices. These private actions contributed substantially to the eradication of typhoid.
} 
maximum burden that a person's risky sexual behavior can impose on third parties. The cheapest means of avoiding AIDS is a condom. Insofar as the magnitude of AIDS interventions is justified by the magnitude of the external costs of AIDS, the implication is that substantial AIDS interventions may not be justifiable.

\section{Conclusion: The future of public choice and public health}

In lieu of recounting what our survey contains, we conclude by way of highlighting what it (mostly) does not. Especially rare in public-choice relevant scholarship that addresses issues in public health are analyses of public health policies that deal specifically with contagious disease. Ryan's (2014) study of the H1N1 vaccine is one exception. Philipson and Posner's (1993) analysis of AIDS policies is another. And Barrett's (2006) examination of smallpox eradication is a third. Still, the dearth of such work is conspicuous-perhaps, however, only in hindsight. In their 1991 paper that sought to bring public health to the attention of public choice scholars, Tollison and Wagner (1991, p. 324) wrote the following about contagious disease: "the control and prevention of contagious diseases has long been the paradigmatic example of public health.... However, the battle against contagious diseases has largely been won, at least in the West." Before circa February 2020, it may therefore have seemed that governmental policy relating to contagious disease was not a particularly important or promising public health issue for public choice scholars to study. Now it is clear that it is.

Attention to the Covid-19 pandemic is at present nearly all-consuming. A flurry of economic research considers it already. And in the pandemic's aftermath an avalanche of economic studies is certain to follow. One silver lining of Covid-if there can be such a thing for a pandemic - is that public choice scholars now will focus their attention not only on issues of public health but on public policies in the context of contagious disease in particular. In March 2020, a \$2.2 trillion Coronavirus Aid, Relief, and Economic Security (CARES) Act became law in the United States-the largest economic stimulus bill in US history. In December 2020, an additional $\$ 900$ billion Covid-relief bill was passed as part of the US Consolidated Appropriations Act of 2021. FDA approval and handling of Covid vaccines remains contentious. Vaccine distribution-based on the federal government's Operation Warp Speed initiative-has just begun. And that is to note only the most significant federal Covid-related policies in the United States. State and local policies demand consideration-from lockdowns to masks to social distancing-not to mention market responses to Covid and Covid-related policies in the rest of the world. We hope that this paper's stocktaking of public-choice relevant scholarship that addresses issues in public health serves as a useful reference for public choice scholars as they turn their attention to studying Covid-related interventions.

\section{References}

Adams, A. F., III., Ekelund, R. B., Jr., \& Jackson, J. D. (2003). Occupational licensing of a credence good: The regulation of midwifery. Southern Economic Journal, 69(3), 659-675.

Adler, J. H., Meiners, R. E., Morris, A. P., \& Yandle, B. (2016). Baptists, bootleggers \& electronic cigarettes. Yale Journal on Regulation, 33(2), 313-361.

Anderson, G. M. (1990). Parasites, profits, and politicians: Public health and public choice. Cato Journal, 9(3), 557-578. 
Anderson, G. M. (1997). Bureaucratic incentives and the transition from taxes to prohibition. In W. F. Shughart II (Ed.), Taxing choice: The predatory politics of fiscal discrimination. (pp. 139-166). New Brunswick Transaction Publishers.

Arrow, K. J. (1963). Uncertainty and the welfare economics of medical care. American Economic Review, 53(5), 941-973.

Barnett, A. H., Beard, T. R., \& Kaserman, D. L. (1993). The medical community's opposition to organ markets: Ethics or economics? Review of Industrial Organization, 8, 669-678.

Barnett, A. H., \& Kaserman, D. L. (1995). The 'rush to transplant' and organ shortages. Economic Inquiry, 33(3), 506-515.

Barrett, S. (2006). The smallpox eradication game. Public Choice, 130(1-2), 179-207.

Barrilleaux, C. J., \& Miller, M. E. (1988). The political economy of state Medicaid policy. American Political Science Review, 82(4), 1089-1107.

Batinti, A. (2016). NIH biomedical funding: Evidence of executive dominance in swing-voter states during presidential elections. Public Choice, 168(3-4), 239-263.

Becker, G. S. (1983). A theory of competition among pressure groups for political influence. Quarterly Journal of Economics, 98(3), 371-400.

Benham, L. (1972). The effect of advertising on the price of eyeglasses. Journal of Law and Economics, 15(2), 164-176.

Benham, L., \& Benham, A. (1975). Regulating through the professions: A perspective on information control. Journal of Law and Economics, 18(2), 421-447.

Blair, R. D., \& Kaserman, D. L. (1991). The economics and ethics of alternative cadaveric organ procurement policies. Yale Journal on Regulation, 8(2), 403-452.

Boyes, W. J., \& Marlow, M. L. (1996). The public demand for smoking bans. Public Choice, 88(1-2), 57-67.

Broscheid, A., \& Teske, P. E. (2003). Public members on medical licensing boards and the choice of entry barriers. Public Choice, 114(3-4), 445-459.

Buchanan, J. M. (1965). The inconsistencies of the National Health Service. . Institute for Economic Affairs.

Buchanan, J. M. (1984). Politics without romance: A sketch of positive public choice theory and its normative implications. In J. M. Buchanan \& R. D. Tollison (Eds.), The theory of public choice-II. (pp. 11-22). University of Michigan Press.

Buchanan, J. M. (1994). Technological determinism despite the reality of scarcity: A neglected element in the theory of spending for medical and health care. In C. Hackler (Ed.), Health care for an aging population. (pp. 57-68). State University of New York Press.

Buchanan, J. M., \& Lindsay, C.M. (1970). The organization and financing of medical care in the United States. In Health service financing, pp. 535-585. London: British Medical Association.

Buchanan, J. M., Tollison, R. D., \& Tullock, G. (Eds.). (1980). Toward a theory of the rent-seeking society. . Texas A\&M University Press.

Buchanan, J. M., \& Tullock, G. (1962). The calculus of consent: Logical foundations of constitutional democracy. . University of Michigan Press.

Camobreco, J. F. (1996). Medicaid and collective action. Social Science Quarterly, 77(4), 860-876.

Carroll, S. L., \& Gaston, R. J. (1981). Occupational restrictions and the quality of service received: Some evidence. Southern Economic Journal, 47(4), 959-976.

Clark, D. J. (1997). Pressure and the division of a public budget. Public Choice, 93(1-2), 179-195.

Congleton, R. D., Grofman, B., \& Voigt, S. (Eds.). (2019). The Oxford handbook of public choice. . Oxford University Press.

Cooper, Z., Kowalski, A. E., Powell, E. N., \& Wu, J. (2020). Politics and health care spending in the United States. NBER Working Paper 23748.

Costa-Font, J., Turati, G., \& Batinti, A. (2020). The political economy of health and healthcare: The rise of the patient citizen. . Cambridge University Press.

DiLorenzo, T. J. (1997). Taxing choice to fund politically correct propaganda. In W. F. Shughart (Ed.), Taxing choice: The predatory politics of fiscal discrimination. (pp. 117-138). Transaction Publishers.

Dupre, R. (1999). 'If it's yellow, it must be butter': Margarine regulation in North America since 1886. Journal of Economic History, 59(2), 353-371.

Friedman, M. (1962). Capitalism and freedom. . University of Chicago Press.

Friedman, M., \& Kuznets, S. (1945). Income from independent professional practice. . NBER.

Gant, P. A., \& Ekelund, R. B., Jr. (1997). Excise taxes, social costs, and the consumption of wine. In W. F. Shughart (Ed.), Taxing choice: The predatory politics of fiscal discrimination. (pp. 247-269). Transaction Publishers. 
Geloso, V., \& March, R. J. (2020). Rent-seeking for madness: The political economy of mental asylums in the US, 1870 to 1910. North Dakota State University Public Choice and Private Enterprise Research Paper.

Gertler, P. J., \& Shah, M. (2011). Sex work and infection: What's law enforcement got to do with it? Journal of Law and Economics, 54(4), 811-840.

Gifford, A., Jr. (1997). Whiskey, margarine, and newspapers: A tale of three taxes. In W. F. Shughart (Ed.), Taxing choice: The predatory politics of fiscal discrimination. (pp. 57-77). Transaction Publishers.

Graddy, E. (1991). Interest groups or the public sdo we regulate health occupations? Journal of Health Politics, Policy and Law, 16(1), 25-49.

Grogan, C. M. (1994). Political-economic factors influencing state Medicaid policy. Political Research Quarterly, 47(3), 589-622.

Haas-Wilson, D. (1986). The effect of commercial practice restrictions: The case of optometry. Journal of Law and Economics, 29(1), 165-186.

Haas-Wilson, D. (1989). Strategic regulatory entry deterrence. Journal of Health Economics, 8, 339-352.

Hegde, D. (2009). Political influence behind the veil of peer review: An analysis of public biomedical research funding in the United States. Journal of Law and Economics, 52(4), 665-690.

Hegde, D., \& Sampat, B. (2015). Can private money buy public science? Disease group lobbying and federal funding for biomedical research. Management Science, 61(10), 2281-2298.

High, J., \& Coppin, C. A. (1988). Wiley and the whiskey industry: Strategic behavior in the passage of the Pure Food Act. Business History Review, 62(2), 286-309.

HIV.gov. (2020). Federal domestic HIV/AIDS programs and research spending. May 12, 2020.

Hoffer, A. J., \& Nesbit, T. (Eds.). (2018). For your own good: Taxes, paternalism, and fiscal discrimination in the twenty-first century. . Mercatus Center at George Mason University.

Hoffer, A. J., \& Pellillo, A. (2012). The political economy of tobacco control spending. Applied Economics Letters, 19(18), 1793-1797.

Hoffer, A. J., Shughart, W. F., II., \& Thomas, M. D. (2014). Sin taxes and sindustry: Revenue, paternalism, and political interest. Independent Review, 19(1), 47-64.

Holcombe, R. (1997). Selective excise taxation from an interest-group perspective. In W. F. Shughart (Ed.), Taxing choice: The predatory politics of fiscal discrimination. (pp. 81-102). Transaction Publishers.

Horpedahl, J. (2020). Bootleggers, Baptists and ballots: Coalitions in Arkansas' alcohol-legalization elections. Public Choice. https://doi.org/10.1007/s11127-020-00822-5.

Kaserman, D. L., \& Barnett, A. H. (1991). An economic analysis of transplant organs: A comment and extension. Atlantic Economic Journal, 19(2), 57-63.

Kessel, R. A. (1958). Price discrimination in medicine. Journal of Law and Economics, 1(1941), $20-53$.

Kleiner, M. M., \& Kudrle, R. T. (2000). Does regulation affect economic outcomes? The case of dentistry. Journal of Law and Economics, 43(2), 547-582.

Kleiner, M. M., Marier, A., Park, K. W., \& Wing, C. (2016). Relaxing occupational licensing requirements: Analyzing wages and prices for a medical service. Journal of Law and Economics, 59(2), 261-291.

Klick, J., \& Stratmann, T. (2007). Diabetes treatments and moral hazard. Journal of Law and Economics, $50(3), 519-538$.

Kousser, T. (2002). The politics of discretionary Medicaid spending, 1980-1993. Journal of Health Politics, Policy and Law, 27(4), 639-671.

Lee, D. R. (1997). Overcoming taxpayer resistance by taxing choice and earmarking revenues. In W. F. Shughart (Ed.), Taxing choice: The predatory politics of fiscal discrimination. (pp. 105-116). Transaction Publishers.

Leeson, P. T. (2020). A normal market. . Mimeo.

Leeson, P. T., King, M. S., \& Fegley, T. J. (2020). Regulating quack medicine. Public Choice, 182(3-4), $273-286$.

Leffler, K. B. (1978). Physician licensure: Competition and monopoly in American medicine. Journal of Law and Economics, 21(1), 165-186.

Libecap, G. D. (1992). The rise of the Chicago packers and the origins of meat inspection and antitrust. Economic Inquiry, 30(2), 242-262.

March, R. J. (2017). Skin in the game: Comparing the private and public regulation of Isotretinoin. Journal of Institutional Economics, 13(3), 649-672.

March, R. J., \& Geloso, V. (2020). Gordon Tullock meets Phineas Gage: The political economy of lobotomies in the United States. Research Policy, 49(1), 103872.

Maurizi, A. (1974). Occupational licensing and the public interest. Journal of Political Economy, 82(2), 399-413.

McChesney, F. S. (1987). Rent extraction and rent creation in the economic theory of regulation. Journal of Legal Studies, 16(1), 101-118. 
McCormick, R. E., \& Tollison, R. D. (1981). Politicians, legislation, and the economy: An inquiry into the interest-group theory of government. . M. Nijhoff.

McMichael, B. J. (2017). The demand for healthcare regulation: The effect of political spending on occupational licensing laws. Southern Economic Journal, 84(1), 297-316.

Mendoza, R. L. (2015). Rents from the essential health benefits mandate of health insurance reform. Health Marketing Quarterly, 32(2), 197-215.

Mobarak, A. M., Rajkumar, A. S., \& Cropper, M. (2011). The political economy of health services provision in Brazil. Economic Development and Cultural Change, 59(4), 723-751.

Munger, M., \& Schaller, T. (1997). The prohibition-repeal amendments: A natural experiment in interest group influence. Public Choice, 90(1-4), 139-163.

Ohsfeldt, R. L., \& Gohmann, S. F. (1992). The economics of AIDS-related health insurance regulations: Interest group influence and ideology. Public Choice, 74(1), 105-126.

Olson, M. (1965). The logic of collective action: Public goods and the theory of groups. . Harvard University Press.

Oxford English Dictionary. (2020). Public health. OED Online.

Paul, C. W., II. (1982). Competition in the medical profession: An application of the economic theory of regulation. Southern Economic Journal, 48(3), 559-569.

Pauly, M. V. (2002). James Buchanan as a health economist. In G. Brennan, H. Kliemt, \& R. D. Tollison (Eds.), Method and morals in constitutional economics: Essays in honor of James M. Buchanan. (pp. 401-409). Heidelberg: Springer.

Peltzman, S. (1973). An evaluation of consumer protection legislation: The 1962 drug amendments. Journal of Political Economy, 81(5), 1049-1091.

Peltzman, S. (1976). Toward a more general theory of regulation. Journal of Law and Economics, 19(2), 211-240.

Peltzman, S. (1987a). The health effects of mandatory prescriptions. Journal of Law and Economics, 30(2), 207-238.

Peltzman, S. (1987b). Regulation and health: The case of mandatory prescriptions and an extension. Managerial and Decision Economics, 8(1), 41-46.

Perry, J. J. (2009). The rise and impact of nurse practitioners and physician assistants on their own and cross-occupation incomes. Contemporary Economic Policy, 27(4), 491-511.

Peterson, B. D., Pandya, S. S., \& Leblang, D. (2014). Doctors with borders: Occupational licensing as an implicit barrier to high skill migration. Public Choice, 160(1-2), 45-63.

Philipson, T. J., \& Posner, R. A. (1993). Private choices and public health: The AIDS epidemic in an economic perspective. . Harvard University Press.

Pigou, A. C. (1920). The economics of welfare. . Macmillan.

Poelmans, E., Dove, J. A., \& Taylor, J. E. (2018). The politics of beer: Analysis of the congressional votes on the beer bill of 1933. Public Choice, 174(1-2), 81-106.

Pracht, E. E., \& Moore, W. J. (2003). Interest groups and state Medicaid drug programs. Journal of Health Politics, Policy and Law, 28(1), 9-39.

Prinz, A. L. (2009). The political economy of smoking regulation and taxation. Public Choice, 141(3-4), 291-303.

Propper, C., \& Reenen, J. V. (2010). Can pay regulation kill? Panel data evidence on the effect of labor markets on hospital performance. Journal of Political Economy, 118(2), 222-273.

Ramseyer, J. M. (2009). The effect of cost suppression under universal health insurance on the allocation of talent and the development of expertise: Cosmetic surgery in Japan. Journal of Law and Economics, 52(3), 497-522.

Reksulak, M., Razzolini, L., \& Shughart, W. F. (Eds.). (2014). The Elgar companion to public choice. (2nd ed.). Edward Elgar Publishing.

Rosenman, R. (2011). The public finance of healthy behavior. Public Choice, 147(1-2), 173-188.

Rowley, C. K., \& Schneider, F. (Eds.). (2004). The encyclopedia of public choice. (2nd ed.). Springer.

Ryan, M. E. (2014). Allocating infection: The political economy of the swine flu (H1N1) vaccine. Economic Inquiry, 52(1), 138-154.

Schaumans, C., \& Verboven, F. (2008). Entry and regulation: Evidence from health care professions. Rand Journal of Economics, 39(4), 949-972.

Schneider, L., Klein, B., \& Murphy, K. M. (1981). Governmental regulation of cigarette health information. Journal of Law and Economics, 24(3), 575-612.

Shepard, L. (1978). Licensing restrictions and the cost of dental care. Journal of Law and Economics, 21(1), 187-201.

Shogren, J. F. (1990). The optimal subsidization of Baptists by bootleggers. Public Choice, 67(2), 181-189. 
Shughart, W. F., II. (1997). The economics of the nanny state. In W. F. Shughart (Ed.), Taxing choice: The predatory politics of fiscal discrimination. (pp. 13-28). Transaction Publishers.

Shughart, W. F., II., \& Smith, J. T. (2020). The broken bridge of public finance: Majority rule, earmarked taxes and social engineering. Public Choice, 183(3-4), 315-338.

Shughart II, W. F., \& Tollison, R. D. (1986). Smokers versus nonsmokers. In R. D. Tollison (Ed.), Smoking and society: Toward a more balanced assessment, pp 217-224. D. C. Heath and Company: Lexington.

Smith, A., \& Yandle, B. (2014). Bootleggers and Baptists: How economic forces and moral persuasion interact to shape regulatory politics. . Cato Institute.

Smith, J. K. (1982). An analysis of state regulations governing liquor store licensees. Journal of Law and Economics, 25(2), 301-319.

Sobel, R. S. (2002). Public health and the placebo: The legacy of the 1906 Pure Food and Drugs Act. Cato Journal, 21(3), 463-479.

Sobel, R. S. (2014). The elephant in the room: Why some states are refusing to expand Medicaid. Applied Economics Letters, 21(17), 1226-1229.

Spithoven, A. (2016). The influence of vested interests on healthcare legislation in the USA, 2009-2010. Journal of Economic Issues, 50(2), 630-638.

Stanziani, A. (2007). Negotiating innovation in a market economy: Foodstuffs and beverages adulteration in nineteenth-century France. Enterprise and Society, 8(2), 375-412.

Stevenson, T. P., \& Shughart II, W. F. (2006). Smoke and mirrors: The political economy of the tobacco settlements. Public Finance Review, 34(6), 712-730.

Stigler, G. J. (1971). The theory of economic regulation. Bell Journal of Economics and Management Science, 2(1), 3-21.

Stigler, G. J. (1976). The size of legislatures. Journal of Legal Studies, 5(1), 17-34.

Svorny, S. (1987). Physician licensure: A new approach to examining the role of professional interests. Economic Inquiry, 25(3), 497-509.

Svorny, S., \& Toma, E. F. (1998). Entry barriers and medical board funding autonomy. Public Choice, 97(1-2), 93-106.

Temin, P. (1979). The origin of compulsory drug prescriptions. Journal of Law and Economics, 22(1), 91-105.

Thomas, D. W., \& Leeson, P. T. (2012). The brewer, the baker, and the monopoly maker. Journal of Entrepreneurship and Public Policy, 1(1), 84-95.

Thomas, M. D., \& Thomas, D. W. (2018). The rise of the regulatory state: Institutional entrepreneurship and the decline of markets for blood. Independent Review, 22(4), 485-506.

Tollison, R. D. (2004). Public choice from the perspective of economics. In C. K. Rowley \& F. Schneider (Eds.), The encyclopedia of public choice. (Vol. I, pp. 191-201). Springer.

Tollison, R. D., \& Wagner, R. E. (1988). Smoking and the state: Social costs, rent seeking, and public policy. . Lexington Books.

Tollison, R. D., \& Wagner, R. E. (1991). Self-interest, public interest, and public health. Public Choice, 69(3), 323-343.

Tollison, R. D., \& Wagner, R. E. (1992). The economics of smoking. . Kluwer.

Troesken, W. (1999). Typhoid rates and the public acquisition of private waterworks, 1880-1920. Journal of Economic History, 59(4), 927-948.

Tullock, G. (1967). The welfare costs of tariffs, monopolies, and theft. Western Economic Journal, 5(3), 224-232.

Tullock, G. (1983). The economics of income redistribution. . Kluwer Nijhoff.

Tullock, G. (1995). The cost of medical progress. American Economic Review, 85(2), 77-80.

Tullock, G. (1997). Excise taxation in the rent-seeking society. In W. F. Shughart (Ed.), Taxing choice: The predatory politics of fiscal discrimination. (pp. 369-372). Transaction Publishers.

Tullock, G., Arthur, S., \& Brady, G. L. (2002). Government failure: A primer on public choice. . Cato Institute.

Tuohy, C. H., \& Glied, S. (2011). The political economy of health care. In S. Glied \& P. C. Smith (Eds.), The Oxford handbook of health economics. (pp. 143-182). Oxford University Press.

Urban, R., \& Mancke, R. (1972). Federal regulation of whiskey labelling: From the repeal of prohibition to the present. Journal of Law and Economics, 15(2), 411-426.

Wagner, R. E. (1997). The taxation of alcohol and the control of social costs. In W. F. Shughart (Ed.), Taxing choice: The predatory politics of fiscal discrimination. (pp. 227-245). Transaction Publishers.

Wagner, R. E. (1999). Understanding the tobacco settlement: The state as partisan plaintiff. Regulation, 22(4), 38-41.

Wagner, R. E. (2004). Meddlesome preferences and rent extraction: The tobacco shakedown. In C. K. Rowley \& F. Schneider (Eds.), The encyclopedia of public choice. (Vol. II, pp. 378-379). Springer. 
Ward, M. R., \& Dranove, D. (1995). The vertical chain of research and development in the pharmaceutical industry. Economic Inquiry, 33(1), 70-87.

Weingast, B. R., \& Moran, M. J. (1983). Bureaucratic discretion or congressional control? Regulatory policymaking by the Federal Trade Commission. Journal of Political Economy, 91(5), 765-800.

Wood, D. J. (1985). The strategic use of public policy: Business support for the 1906 Food and Drug Act. Business History Review, 59(3), 403-432.

Yandle, B. (1983). Bootleggers and Baptists: The education of a regulatory economist. Regulation, 7(3), $12-16$.

Yandle, B. (1999). Bootleggers and Baptists in retrospect. Regulation, 22(3), 5-7.

Publisher's Note Springer Nature remains neutral with regard to jurisdictional claims in published maps and institutional affiliations. 